\title{
The Financing of Investment: Firm Size, Asset Tangibility and the Size of Investment
}

\author{
Mathias Lé ${ }^{1}$ and Frédéric Vinas ${ }^{2}$ \\ July 2020, WP \#777
}

\begin{abstract}
How do firms finance their investment? To what extent does the financing mix depends on the nature or the size of investment? To what extent does the funding mix of investment vary along firm size? Relying on a unique database of firms covering $72 \%$ of the value added in France over three decades, this paper addresses those questions and provides a comprehensive picture of the financial resources used by firms to finance their investment. We uncover significant cross-sectional heterogeneity in the financing mix of investment along firm size, asset tangibility and investment size. In particular, we show that the commonly held view that "firms strongly rely on bank credit in a bank-based economy" weakens significantly as we consider larger firms or when it comes to finance intangible investments or relatively small investments.
\end{abstract}

Keywords: Investment, Working Capital, Firm Financing, Bank Credit, Equity Finance, Retained Earnings, Firm Size, Investment Spikes

JEL classification: D25; E22; G21; G30; G31; G32

\footnotetext{
${ }^{1}$ Banque de France, mathias.le@,banque-france.fr

${ }^{2}$ Banque de France, frederic.vinas@,banque-france.fr

The opinions expressed in this paper do not necessarily reflect views of the Banque de France. We would like to thank Vincent Bignon, Paul Beaumont, Christophe Cahn, Anne Duquerroy, Erwan Gautier, Olivier Gonzalez, Clément Mazet-Sonilhac, Jean-Stéphane Mésonnier, Frédérique Savignac and Jean-Pierre Villetelle for helpful discussions and comments. We are especially thankful to Olivier de Jonghe for a fruitful discussion. We also thank seminar participants at the ACPR, the Banque de France, the $67^{\text {th }}$ International Congress of the French Economic Association and the 36th Symposium in Money Banking and Finance.
}

Working Papers reflect the opinions of the authors and do not necessarily express the views of the Banque de France. This document is available on publications.banque-france.fr/en 


\section{NON-TECHNICAL SUMMARY}

The lack of corporate investment has been identified as one of the major weaknesses in the aftermath of the 2008 crisis (Banerjee et al. 2015, Fay et al. 2017). Several explanations have been proposed, ranging from decreased competition (Gutiérrez and Philippon, 2017) to the rise of intangible assets and globalization (Alexander and Eberly, 2018) or financial factors (Acharya and Plantin, 2019). However, we still know too little about how firms put together various financial resources to undertake new investments. And to what extent does the financing mix depends on the nature or size of the investment or firm size?

To tackle those questions, we resort to a methodological framework commonly used in the international trade literature (Eaton et al. 2004, among others) and recently employed in the corporate finance literature (Frank and Goyal 2003, among others). This methodology enables to quantify the contribution of each of these funding sources to the financing of firms' investment. In practice, we investigate to what extent different funding sources (bank credit, financial debts, equity, retained earnings and cash holdings) contribute to finance both fixed assets and working capital assets accumulation. Our study also examine to what extent these financing patterns are likely to vary with the nature of assets (tangible vs. intangible assets), the size of the firms and the size of the investments undertaken.

This paper provides a comprehensive picture of the funding sources used by firms to undertake new investments and to finance their working capital assets. For this purpose, we use financial statements from a sample of French firms covering $72 \%$ of the value added of non-financial corporations in 2018, from very small firms to the largest ones, over the last three decades. Our findings are the following.

First, bank credit appears critical to the financing of investment for the vast majority of firms: we estimate its contribution to the financing of fixed assets accumulation to be around $60 \%$. The remaining funding sources are (i) the other financial debts, (ii) the retained earnings and (iii) the cash holding, each of them contributes to more or less $10 \%$ of the financing needs.

We then find that, the contribution of bank credit to fixed assets investment strongly decreases as we consider larger firms: from $60 \%$ for the bottom $25 \%$ of the distribution of firm size, the contribution of bank credit is estimated to be only $40 \%$ for the top $5 \%$ largest firms. At the same time, the contribution of other financial debts and equity funding are found to be largely increasing with firm size. In contrast, we find that the contribution of bank credit to fund working capital assets is rather independent on firm size (around 19\%).

Third, we show that bank credit strongly contributes to the funding of tangible fixed assets ( $43 \%$ in the weighted-OLS estimation) but to a lower extent to the funding of intangible fixed assets $(23 \%)$. Indeed, intangible fixed assets rely proportionally more on equity $(17 \%$ vs $7 \%$ for tangible fixed assets) and other financial debts (30\% vs $20 \%$ ). Retained earnings and cash holdings play no significant role in the funding of intangible fixed assets.

Finally, we show that the funding mix also changes significantly depending on the size of investment. Bank credit strongly contributes to fund large investments $(46 \%)$ but much less to fund small investments (30\%). On the contrary, internal financial resources and most notably retained earnings emerge as an important source to finance small investments. 


\section{Share of firms relying on bank credit while investing}

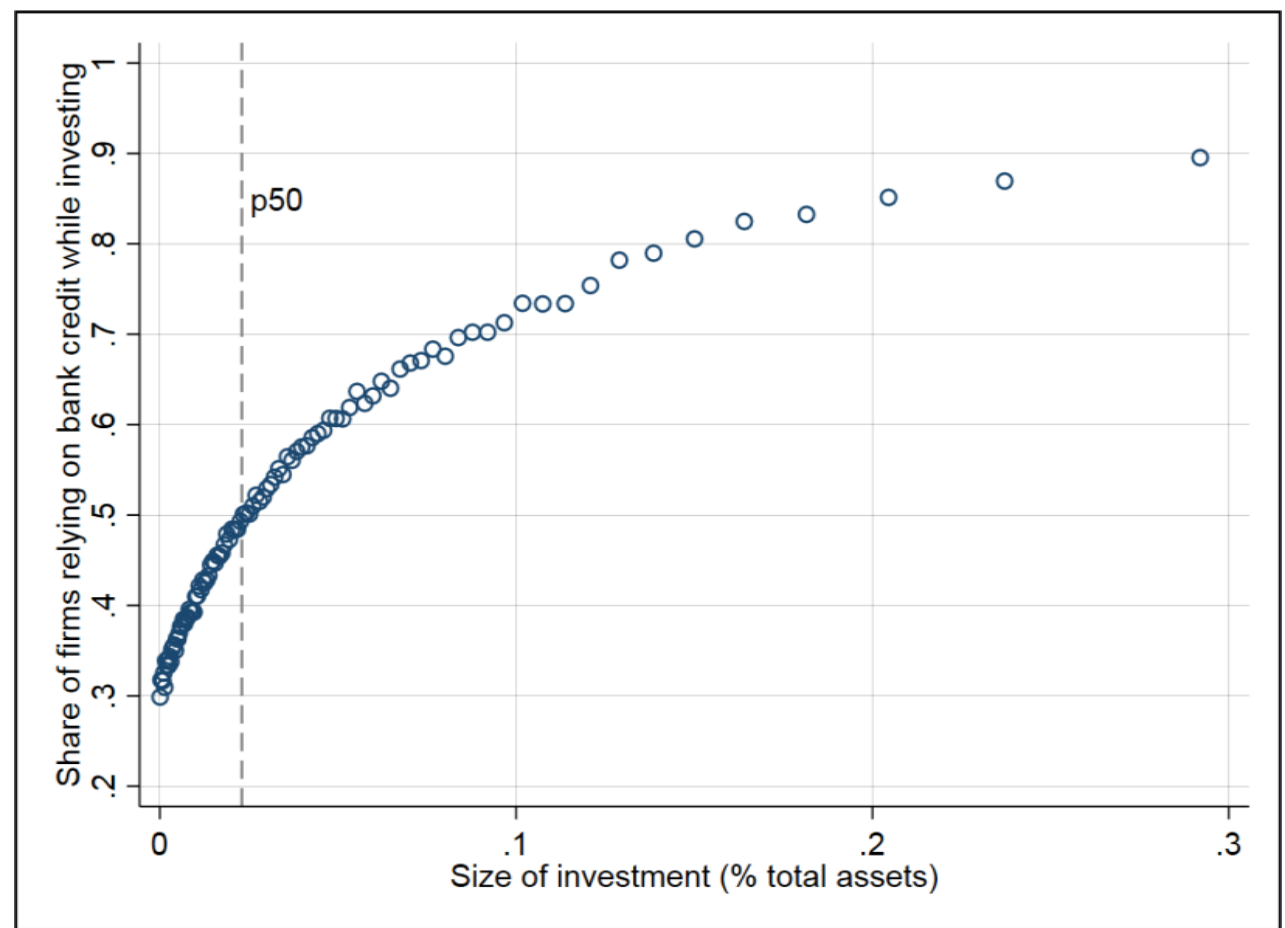

This figure shows the share of firms relying on bank credit (y-axis) depending on the investment size they carry out (x-axis). Reading: $90 \%$ of firms increasing their fixed assets by $29 \%$ (of their total assets) rely on bank credit. The $10 \%$ remaining does not rely on bank credit for such an investment.

\section{Le financement de l'investissement : taille des entreprises, taille et nature de l'investissement}

\section{RÉSUMÉ}

Comment les entreprises financent elles leur investissement? En quelle mesure la stratégie de financement dépend de la nature, de la taille de l'investissement ou de la taille de l'entreprise ? À partir de données individuelles d'entreprises représentant $72 \%$ de la valeur ajoutée en France et couvrant trois décennies, notre travail adresse ces questions et fournit une description complète de la contribution de différentes ressources au financement de l'investissement. Nous montrons une forte hétérogénéité en coupe dans la stratégie de financement en fonction de la taille de l'entreprise, de la taille de l'investissement et de la nature de l'investissement. Nous montrons que la vision répandue du rôle central du crédit bancaire dans une "économie bancaire » s'affaiblit lorsque l'on considère le financement d'immobilisations incorporelles, de petits investissements ou pour les grandes entreprises.

Mots-clés : investissement, besoin en fonds de roulement, financement, crédit bancaire, equity, mise en réserve, taille d'entreprise, pic d'investissement

Les Documents de travail reflètent les idées personnelles de leurs auteurs et n'expriment pas nécessairement la position de la Banque de France. Ils sont disponibles sur publications.banque-france.fr 


\section{Introduction}

The lack of corporate investment has been identified as one of the major weaknesses in the aftermath of the 2008 crisis (Banerjee et al. 2015, Fay et al. 2017). Several explanations have been proposed, ranging from a decreasing competition (Gutiérrez and Philippon, 2017) to the rise of intangible assets and globalization (Alexander and Eberly, 2018) or financial factors (Acharya and Plantin, 2019). Regarding the latter, we have learned a lot about the way funding shocks affect firm's investment thanks to the numerous recent empirical investigations based on micro-data. However, we still know too little about how firms put together various financial resources to undertake new investments. For instance, corporate investment may be highly elastic to bank credit even though bank credit only represents a small share of investment financing.

Against this background, this paper provides a comprehensive picture of the funding sources used by firms to undertake new investments and to finance their working capital assets. For this purpose, we use financial statements from a sample of French firms covering $72 \%$ of the aggregate value added of non-financial corporations in 2018, from very small firms to the largest ones, over the last three decades. By the range of assets and liabilities considered, the number and the size of firms reviewed as well as the time period covered, the present paper is unique.

We study the financing of investment in relation with distinctive economic trends of these last decades. First, the cross-sectional heterogeneity in firm's size has increased significantly (Reenen, 2018, Bernard et al., 2019) and it is now well documented that the firm size distribution is closer to a power law in many countries (Gabaix 2009). As a result, we explore how the funding mix of corporate investment varies across firm's size. Second, in a period of slow growth (Gordon 2016) where innovation plays an increasing role in the economy, it seems crucial to better understand to what extent the financing patterns of tangible and intangible investments differ. Third, the dichotomy between investment spikes and routine investments has attracted a lot of attention recently (Elsas et al., 2013, Disney et al. 2020 or Im et al., 2020) and it is thus important to better understand to what extent the financing mix of large and small investments may differ and how these differences interacts with firms' size or the nature of investment.

To tackle those questions, we resort to a conceptual and methodological framework commonly used in the international trade literature (Eaton et al. 2004, Bernard et al. 2007 or Morrow and Trefler 2017) and recently employed in the corporate finance literature (Frank

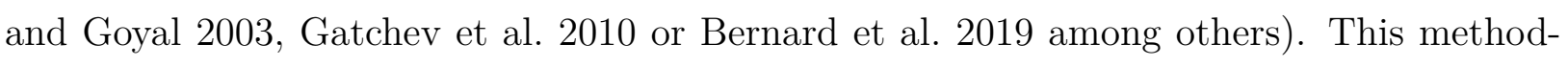
ology akin to a variance decomposition provides a measurement of how much of the overall variations in fixed and working capital assets of firms can be related to variations in each of the funding sources. Said differently, the methodology enables to quantify the contribution of each of these funding sources to the financing of firms' investment. This empirical 
framework is however not causal and rather descriptive. The parameters that we estimate are useful correlations to better understand how firms combine different financial resources together to finance their capital expenditures in practice. However, these parameters do not inform us on how changes in a given funding source is likely to affect capital expenditures of firms. In particular, a given source of funds may only cover a small share of the financing needs but nonetheless be an essential prerequisite to investment decisions.

Using a dataset gathering 2.3 million financial statements from almost 177,000 firms operating in France over the last thirty years, we start by estimating the unconditional contributions of various funding sources (bank credit, financial debts, equity, retained earnings and cash holdings) to the financing of both fixed assets and working capital assets accumulation. We first estimate these contributions using simple OLS. However, the distribution of most corporate outcomes is skewed toward the largest firms, i.e. the largest firms make the lion share of aggregate quantities. As a result, we also estimate the contributions using OLS weighted by firm size. The first set of results provides us with a picture describing how the vast majority of small firms finance their investment expenditures while the second set of results offers an aggregate view on the financing of the corporate investment.

We uncover several interesting patterns. First, bank credit appears critical to the financing of investment for the vast majority of firms: we estimate its contribution to the financing of fixed assets accumulation to be around $60 \%$. The remaining funding sources are (i) the other financial debts, (ii) the retained earnings and (iii) the cash holdings: each of them contributes to more or less $10 \%$ of the financing needs. Strikingly, and in contrast with similar estimations on US data, the estimated role of equity finance is extremely limited at this stage (less than 1\%). We also find that the financing of working capital assets investment is significantly more balanced across funding sources with a prominent role for cash holdings. Then, we take into account firm size heterogeneity by re-estimating these contributions through weighted-OLS and we observe significant changes in the patterns previously identified. Regarding the fixed asset investment, the contribution of bank credit is lowered by one-third, at around $40 \%$, while the estimated contribution of other financial debts rises to $20 \%$. But the most significant change relates to equity finance which is no longer marginal at all: its contribution is now estimated at $10 \%$, as much as retained earnings or cash holdings. Our findings complement usefully those from Gatchev et al. (2009) based on US data: while that paper underlines the prominent role of equity funding in a market-based financial system, we document the essential role of bank credit in a bank-based economy through its role in the funding of investment.

We deepen our investigation by examining to what extent the contributions vary along firm's and investment's characteristics. First, a distinctive feature of our dataset is to provide balance sheet information about small firms that generally fall out of the scope of most corporate finance studies.1] We take advantage of that specificity to explore how the

\footnotetext{
${ }^{1}$ While the median non-financial firm in Compustat over the period 1994-2005 has total sales around
} 
financing mix of capital expenditure is affected by firm size. Indeed, small and large firms differ a lot in terms of productivity, profitability or capital structure. It is generally admitted that small firms face more severe credit constraints (Beck et al. 2008, Gertler and Gilchrist 1994, Hadlock and Pierce 2010), have a different cyclicality (Covas and Haan 2011, Crouzet and Mehrotra 2020) and have a more limited access to financial markets than large firms. Additionally, many recent papers have documented that investment of small and large firms react with a different intensity to funding shocks (Chaney et al. 2012, Mian and Sufi 2014 or Chodorow-Reich 2014a). As a result, the financing of investment should vary significantly across firm size and this should materialize through different estimated contributions in our setting. To this end, we use a time-varying quantile decomposition and we estimate the contribution of each of the funding sources to investment in fixed assets and working capital assets by size class.

We find that the contribution of bank credit to fixed assets investment strongly decreases as we consider larger firms: from $60 \%$ for the bottom $25 \%$ of the distribution of firm size, the contribution of bank credit is estimated to be only $25 \%$ for the top $5 \%$ largest firms. At the same time, the contribution of other financial debts and equity funding are found to be largely increasing with firm size. As a result, larger firms are much less dependent on bank credit when it comes to invest in new fixed assets and they make use of alternative financial instruments like bonds and equity to cover the remaining funding needs. Hence, even in a bank-based financial system, equity finance can play a significant role regarding the financing of capital accumulation. The next investigation will provide additional evidence regarding the role of equity finance.

Indeed, a prominent and well-documented economic trend observed over the last twenty years is the changing nature of investment and the rise of intangible investment (Haskel and Westlake 2018). The rising use of intangible capital generates a lot of debates on how to measure it (Corrado et al. 2009 Peters and Taylor 2017) and how this can affects firm-level and aggregate productivity. At the same time, the rapidly changing nature of investment should not be without effect on the financing of investment and we explore this question by estimating the contribution of various funding sources to the financing of tangible and intangible investment separately. As a result of the lack of pledgeability of intangible capital, the financing of intangible investments requires to overcome the "tyranny of collateral" and we expect to find the financing mix of intangible capital accumulation to be more oriented toward financial instruments requiring no collateral, namely equity financing and internal financing.

The results confirm this hypothesis: investments in tangible fixed assets requires a proportionally larger fraction of funding coming from bank credit than investments in intangible

$\$ 90 \mathrm{M}$ (Lemmon et al. 2008), the median non-financial firm in our sample has total sales of $€ 2.66 \mathrm{M}$. In particular, $25 \%$ of the firms in our sample have total sales lower than $€ 1.5 \mathrm{M}$ and $95 \%$ of them lower than $€ 30 \mathrm{M}$ to $€ 40 \mathrm{M}$. 
fixed assets ( $43 \%$ vs. $23 \%$ in the weighted-OLS estimation). Consequently, the financing of investment in intangible fixed assets relies proportionally more on other financial debts $(30 \%$ vs. $20 \%)$ and equity finance $(17 \%$ vs. $7 \%)$. Interestingly, internal resources like retained earnings and cash holdings play no role at all in the funding of intangible investment while it accounts for up to $20 \%$ of the financing of investment in tangible fixed assets. Our findings thus confirm that the specific nature of intangible capital (low redeployability, nonexclusiveness, and low liquidity) necessitates dedicated financing mixes (Hall and Lerner 2010, Borisova and Brown 2013).

We finally explore a third and more innovative dimension that could affect the financing patterns of investments: the size of investments undertaken. For many reasons, the funding mix should depend on investment size. First, large investment (land, machine or building for instance) are more likely to be pledgeable than smaller investment (furniture and fixtures or computer equipment for instance). ${ }^{2}$ Second, firms undertaking large investments exhaust more quickly their internal funding (Chay et al., 2015). Third, small investments are more frequent (Whited, 2006), less predictable but also less uncertain: internal funding is thus better suited to finance these small investments because it is a financial resource which is more readily available. Overall, we conjecture that small investments are financed with proportionally more internal funding (retained earnings or cash holdings) while large investments use proportionally more bank credit or bond financing.

We bring convincing evidence that support this view. We first find that larger investment (defined as changes in fixed assets over total assets above the median) are more systematically associated with changes in bank credit (and changes in other financial debts and equity as well): in the weighted-OLS regressions, the contribution of bank credit to large changes in fixed assets is $50 \%$ higher than for small changes (46\% against 30\%). Second, internal resources play a prominent role in the financing of small investment: the contribution of retained earnings to the financing of new investments is as high as $20 \%$ to $30 \%$ depending on the specification. This makes retained earnings the second most important sources of funds when it comes to finance small investments. Those funding patterns across investment size are at play both for tangible and intangible investment. We also establish that these differences in the financing mix of small $v s$. large investments are observable over the entire range of firm size, even if the discrepancy between the financing of large and small investments is reduced as we consider larger firms.

The contribution of this paper is threefold. First, to the best of our knowledge, we are the first to study in depth how investments of different size lead to distinct financing patterns. A few studies have explored this issue, albeit in a different way. Most notably, Chay et al. (2015) examine the financing hierarchy of US firms using a quantile regression framework

\footnotetext{
${ }^{2}$ These assets have presumably higher liquidation values (because of longer depreciation period as well as existence of secondary markets) and this increases the debt capacity of firms (Chaney et al. 2012, Aretz et al. 2020) and their investment (Cerqueiro et al., 2019).
} 
to evaluate the sensitivity of investment to various financial resources, in the spirit of the investment-cash flow literature (Fazzari et al. 1988). They found that investments are more responsive to internal funds than to external funds at almost all levels of investments, except at top investment levels where investments become more responsive to external funds than to internal funds. ${ }^{3}$ In contrast, we rather use an alternative framework borrowed from the trade literature (Eaton et al., 2004) that makes possible to decompose in a comprehensive way the fluctuations of fixed assets into fluctuations of the various funding sources. This decomposition is valuable because, contrary to the investment-cash flow sensitivity empirical framework, we can directly compare the estimated contributions of different funding sources with each other.4. Another recent paper by Elsas et al. (2013) has analyzed the financing of very large investment. However, unlike the present study that estimates the contribution of different funding sources to large investments, they rather use these infrequent but large investment decisions in an event-study framework to test capital structure theories.

Second, unlike most papers in corporate finance, and in particular Gatchev et al. (2009) which is the closest to our investigation, we study how firm finance their investments in a bank-based financial system (as opposed to market-based financial systems like the US, see Levine, 2002). Our paper contributes to the literature by making possible to compare firm-level estimations of the funding strategy of firms across the two types of system. In particular, our findings support the idea that firms fund differently their investments in bank-based vs. market-based financial systems and clarify the extent of these differences across funding sources: $5^{5}$

Third, our data enable to examine in details the financing patterns of very small firms that generally slip under the radar of corporate financial studies. The current understanding of the financing patterns of very small firms relies almost exclusively on surveys (Beck and Demirguc-Kunt 2006 or Beck et al. 2008 for instance). We are thus among the first to examine the financing patterns of this population of micro-enterprises (those with total sales below $€ 2 \mathrm{M}$ which represent half of our sample) using financial statements. ${ }^{6}$ Our analysis confirms the distinctiveness of the very small firms regarding the financing of investment as well as the importance to better understand these patterns of financing.

The paper is organized as follows. The next section presents the methodology and the empirical strategy. Then, we provide details about the data and some descriptive statistics. After that, we present and discuss the results before concluding.

\footnotetext{
${ }^{3}$ They also established that investments are more responsive to equity financing than to debt financing at low and medium investment levels, although the reverse is true at high investment levels.

${ }^{4}$ Precisely, in a classical investment-cash flow regression, the mere comparison of estimated coefficients associated with two distinct sources of funds does not inform us about the contributions of each of them to the funding of investment. It rather indicates different elasticities of investment to each of these funding sources, abstracting from endogeneity issues.

${ }^{5}$ Indeed, the significant differences in accounting norms and balance sheet reporting between France and the US make the comparative exercise difficult.

6 Crouzet and Mehrotra (2020) study the cyclicality of a similar population of US firms.
} 


\section{Conceptual framework and empirical strategy}

The main objective of this paper is to provide a quantitative assessement of the role of various funding sources (bank credit, equity issuance, retained earnings...) in the financing of fixed assets and working capital assets investment in France over the last thirty years. For this purpose, we resort to a framework previoulsy used in several papers in corporate finance (Frank and Goyal 2003, Gatchev et al. 2009, Gatchev et al. 2010 or Dasgupta et al. 2011 among others). Basically, this consists in regressing selected accounting identities to estimate systematic relations between asset and liability side components. This procedure is analogous to Eaton et al. (2004) variance decomposition commonly used in the international trade literature and recently implemented in Hottman et al. (2016) to quantify the sources of firm's heterogeneity. In this section, we present this framework and we then explain how we build our main variables of interest and the resulting accounting identities that we estimate.

\subsection{A brief and intutitive overview of the methodology}

For the sake of simplicity and without loss of generality, assume a very stylized balance sheet where the firm has a single asset to fund (fixed assets $F A$ ) and two types of liability (equity $E$ and bank credit $B C$ ). The resulting accounting identity at each period $t$ is written:

$$
F A_{t} \equiv B C_{t}+E_{t} \Longleftrightarrow \Delta F A_{t} \equiv \Delta B C_{t}+\Delta E_{t}
$$

Here, $\Delta F A_{t}$ denotes the changes in fixed assets between two periods, namely the flow of new investment between $t-1$ and $t$, while $\Delta B C_{t}$ and $\Delta E_{t}$ indicates the flows of new bank credit and new equity issuance. Starting from this stylized accounting identity, the methodology we use consists in estimating the two following regressions:

$$
\left\{\begin{array}{l}
\Delta B C_{t}=\alpha_{1}+\beta_{1} \cdot \Delta F A_{t}+\epsilon_{1, t} \\
\Delta E_{t}=\alpha_{2}+\beta_{2} \cdot \Delta F A_{t}+\epsilon_{2, t}
\end{array}\right.
$$

In this setting, the coefficients $\hat{\beta}_{i}$ have a straightforward interpretation: they provide us with a measurement of how much of the overall variation in firm investment $\left(\Delta F A_{t}\right)$ can be attributed to variations in each of the funding source $\left(\Delta B C_{t}\right.$ and $\left.\Delta E_{t}\right)$. To see this, we use the properties of ordinary least squares:

$$
\left\{\begin{array}{l}
\hat{\beta}_{1}=\frac{\operatorname{cov}\left(\Delta F A_{t}, \Delta B C_{t}\right)}{\operatorname{var}\left(\Delta F A_{t}\right)} \\
\hat{\beta}_{2}=\frac{\operatorname{cov}\left(\Delta F A_{t}, \Delta E_{t}\right)}{\operatorname{var}\left(\Delta F A_{t}\right)}
\end{array}\right.
$$

As a result, the following equality must hold, $\hat{\beta}_{1}+\hat{\beta}_{2}=1$, and $\hat{\beta}_{1}$ and $\hat{\beta}_{2}$ represent the share of the overall variation in firm investment explained by variations in each funding 
source. 7 This framework can be conveniently extended to richer accounting identities.

\subsection{Definition of variables and balance sheet identities}

As we will explain in more details in the next section, we use information coming from a dataset gathering the balance sheet statements of French firms. 8 We decompose the asset side of the balance sheet of firms into four components: (net) fixed assets $\left(F A_{t}\right)$, i.e. machinery, buildings and productive assets, (net) working capital assets, defined as the sum of inventories and trade receivables less trade payables $\left.\left(W C A_{t}\right)\right)^{9}$, cash holdings $\left(C H_{t}\right)$ and residual assets $\left(R A_{t}\right)$. Likewise, the liability side is broken down into four main components: equity or equity $\left(E_{t}\right)$, bank credit $\left(B C_{t}\right) \sqrt{10}$, other financial debts $\left(O D_{t}\right)$ and residual liabilities $\left(R L_{t}\right)$ which is mainly composed of company's tax and social debts.

The resulting accounting identity must hold at any time $t$ :

$$
F A_{t}+W C A_{t}+R A_{t}+C H_{t} \equiv E_{t}+B C_{t}+O D_{t}+R L_{t}
$$

We only observed stock variables and we are interested in flow variables (fixed assets investment, working capital investment, flow of new bank credit, equity issuance...). Because we do not have cash-flow statements in our dataset (as it is the case in some well known datasets like Compustat that provide a standardized Statement of Cash Flows), we must compute the flow variables as the yearly first-difference of stock variables. As a result, the main accounting identity states that the sources of funds must equal the uses of funds at any time $t$. Importantly, we choose to consider changes in cash holdings $\left(\Delta C R_{t}\right)$ as a source of fund rather than a use of fund:

$$
\Delta F A_{t}+\Delta W C A_{t}+\Delta R A_{t} \equiv \Delta E_{t}+\Delta B C_{t}+\Delta O D_{t}+\Delta R L_{t}-\Delta C H_{t}
$$

We can further refine this accounting identity in the following way. First, note that the law of motion of total equity from one period to another writes:

$$
\Delta E_{t}=\Delta \widetilde{E}_{t}+\pi_{t}
$$

This relation states that the changes in total equity between $t-1$ and $t$ are equal to the sum of equity issuance/buy-back $\left(\Delta \widetilde{E}_{t}\right)$ and net current income $\left(\pi_{t}\right)$. Note also that the firm's net current income at the end of year $t$, denoted by $\pi_{t}$, can be divided into (i)

\footnotetext{
${ }^{7}$ see Bernard et al. 2019 for a similar approach decomposing firm's total sales into upstream, downstream, and final demand margins.

${ }^{8}$ In the appendix 9.1 , additional information about the definition of the variables are provided

${ }^{9}$ By considering the net working capital assets after netting out trade receivables and trade payables, we implicitly assume that firms try to finance their inventories and trade receivable by first matching them with trade payables. This is not an unreasonable assumption though as we will show latter using correlations.

${ }^{10}$ Bank credit will then be further decomposed into ST and LT bank credit.
} 
the dividends paid out to shareholders $\left(D_{t}\right)$ and (ii) the retained earnings, i.e. the fraction of the net income that is not distributed. This latter component can be used to invest, to acquire new assets, to deleverage or to increase the firm's equity base. We denote by $R E_{t}=\pi_{t}-D_{t}$ the fraction of current income which is not paid out to shareholders, i.e. retained earnings. As a result, the previous equation now writes:

$$
\Delta E_{t}=\Delta \widetilde{E}_{t}+R E_{t}+D_{t}
$$

We observe $\Delta E_{t}, \pi_{t}$ and $D_{t}$ but not $\Delta \widetilde{E}_{t}$ that we must infer from the other components: $\Delta \widetilde{E}_{t}=\Delta E_{t}-\pi_{t}$. Because we are not particularly interested in analyzing dividend policy, we ignore the dividend component in the liability side and we deduct these dividends paid out from the cash holding in the asset side in order to make asset and liability side consistent: $\Delta \widetilde{C H}_{t}=\Delta C H_{t}-D_{t} \sqrt{11}$ Finally, we rewrite the accounting identity $(5)$ in the following way:

$$
\Delta F A_{t}+\Delta W C A_{t}+\Delta R A_{t} \equiv \Delta \widetilde{E}_{t}+R E_{t}+\Delta B C_{t}+\Delta O D_{t}-\Delta \widetilde{C H_{t}}+\Delta R L_{t}
$$

This accounting identity relates the sources of funds (right-hand side) to the uses of funds (left-hand side) at each period $t$. Importantly, given our long time serie, all the variables are deflated using the gross fixed capital formation price index as deflator ${ }^{12}$ Similarly, all variables are scaled using the total assets in year $t-1$. Hence, a 0.01 increase in investment $\Delta F A_{t}$ indicates a change in deflated fixed assets corresponding to $1 \%$ of deflated total assets.

\section{$2.3 \quad$ Estimation strategy}

In the next sections, we apply the methodology presented in the section 2.1 to the accounting identity (8). We provide estimates of the contribution of various sources of funds to the financing of investment by regressing each funding source on all possible uses of funds. From this perspective, our paper is closely related to those of Gatchev et al. $(\overline{2009})$ and Gatchev et al. (2010).

Starting from the accounting identity (8), we first estimate the $k$ following regressions:

$$
\Delta Y_{t}^{k}=\alpha^{k}+\beta^{k} \cdot \Delta F A_{f, t}+\gamma^{k} \cdot \Delta W C A_{f, t}+\omega^{k} \cdot \Delta R A_{f, t}+\epsilon_{f, t}^{k} \text { if } \Delta F A_{f, t}>0
$$

We estimate these equations by replacing $\Delta Y_{t}^{k}$ with all possible sources of funds $k$ one after another. As the accounting identity (8) isolates 6 differents sources of funds, we regress 6 differents equations and we obtain 6 differents estimates of $\beta^{k}$ and $\gamma^{k}$ corresponding to

\footnotetext{
${ }^{11}$ We could alternatively keep the dividends paid out in the balance sheet by considering the current income and not the retained earnings. By doing so, we will only affect marginally our estimate of the contribution of retained earnings. Said differently, this choice is largely irrelevant regarding the main findings of this paper.

${ }^{12}$ Available here https://www.insee.fr/fr/statistiques/fichier/2832670/t_6303.xls
} 
the estimated contribution of each of the funding source $k$ to the financing of fixed assets investment and working capital assets investment respectively ${ }^{13}$ When estimating these equations, we restrict the sample to firms with positive change in fixed assets, i.e. we limit our estimation to the set of firms that invest because we are interested in better understanding how firms adjust their balance sheet when facing investment decision and not so when facing disinvestment decisions. The main conclusions are nonetheless unaltered if we remove this restriction and consider disinvestment decisions as we show in appendix.

We control for a set of standard ratios in corporate finance likely to affect investment decisions: the share of equity over total assets, the share of cash holdings over total assets, the share of bank credit over total assets, the growth rate of sales, the ratio of dividends to sales and finally the log of total assets. All the variables used are demeaned in order to remove firm level, time-invariant heterogeneity and all our estimations are clustered at the firm level (Petersen 2008).

Our framework is suited to provide two different views about the financing of investment. In the first case, we can estimate unweighted regressions, i.e. we give the same weight to all firms, irrespective of their size. The estimated parameters then provide valuable information about the financing mix of the vast majority of firms, namely SMEs. Alternatively, our regressions can be weighted by firm size (total sales or total assets for instance) in order to give a larger weight to larger firms. Indeed, the distribution of French firms is heavily skewed toward large firms and these big firms represent a considerable fraction of agregate employment, investment, sales or total assets as it is documented in the section 3.2 . Consequently, by weighting our regressions, we provide results that are more consistent with a macroeconomic perspective. It is all the more important as the heterogeneity within size classes increases when we consider higher quantiles of the distribution of firm size. Therefore, if the very largest firms behave differently from the other firms as the findings of Covas and Haan (2011) or Crouzet and Mehrotra (2020) suggest, the weighted estimations are more likely to bring out this specific financing patterns of the largest firms. Our findings support this argument.

In a second step, we will enrich this framework to explore to which extent the estimated contribution of each funding sources is likely to vary along important firm's and investment's characteristics. In particular, we first test whether the financing mix of investment changes with firm size (as Gala and Julio (2016) suggest by documenting a crucial role of firm size in investment decisions). Then, we investigate to which extent these estimated contributions to the financing of investment vary along the nature of investment: tangible vs intangible investment ${ }^{14}$ Finally, we examine how the financing patterns change with the

\footnotetext{
${ }^{13}$ For the sake of brevity, we will not examine the financing patterns of residual assets as it is complicated to give a clear interpretation of what it is.

${ }^{14}$ Measuring intangible investment at the aggregate or at the firm level is challenging and subject to intense debates (Corrado et al. 2009) Indeed, it is generally admitted that, as a result of accounting rules, important expenses realized by firms must be expensed and cannot be capitalized (R\&D and SG\&A expenses mainly).
} 
size of investments undertaken. Indeed, as explained and documented by Chay et al. (2015) who investigate the relevance of the pecking order theory at various level of investment, "the relative contribution of external funds could increase with the level of investments due to the limited availability of internal funds [...] and the relative contribution of equity financing could increase with the level of investments as firms exhaust debt capacity.".

We then run a set of tests to ensure the robustness of our findings before concluding. In particular, we will also refine the framework to take into account the possible intertemporal dependencies in financing and investment decisions (Gatchev et al. 2010 and Dasgupta et al. 2011) by adding leads and lags in our regression set-up.

\section{Data}

\subsection{Presentation of the dataset}

Our empirical analysis is based on a database called FIBEN (Fichier Bancaire des Entreprises) maintained by the Banque de France. This administrative database gathers financial and tax statements of a wide set of non-financial firms operating in France 15 Crucially, it includes a substancial fraction of small firms that generally fall out of the scope of most corporate studies. Information about firms are collected on a yearly basis by the Banque de France from certified public accountants. ${ }^{16}$ The data are available from 1989 to 2016. Firm's reporting occurs at the legal entity level (unconsolidated accounts), through a unique national identifier called SIREN.

The main collection criterion is based on firm's sales: information are collected for any firm whose total sales are over $€ 750 \mathrm{~K}$. ${ }^{17}$ The database thus covers a large share of the French economy. A Banque de France's internal report analyzed the database coverage in 2015: it appears that the FIBEN dataset covers $31 \%$ of individual firms in 2015, but those firms represent $72 \%$ of the total value added in 2018.18

For the purpose of our empirical analysis, we impose usual restrictions to the data. First,

Hence, the measure of intangible capital as it appears in the balance sheet is likely to underestimate the true extent of intangible investment. See Peters and Taylor (2017) for more details.

${ }^{15} \mathrm{An}$ important role of the FIBEN dataset is to feed analysts of the Banque de France with quantitative and financial information about firms in order to conduct a comprehensive assessment of a company's credit risk with a view to awarding it a rating.

${ }^{16}$ In case where the data are not provided by a certified public accountants, information comes from registers of commercial courts.

${ }^{17}$ Alternative collection criteria are threefold: (i) the firm's total banking debt is higher than $€ 380 \mathrm{~K}$, or (ii) the firm lost half of its capital share during the year, or (iii) the firm fulfilled the $€ 750 \mathrm{~K}$-sales threshold in the previous year. In 2012, those collection criteria changed: starting from 2013, only the first criteria on the $€ 750 \mathrm{~K}$-sales threshold is kept, other criteria being removed. Note also that all those criteria have not to be fullfilled simultaneously.

${ }^{18}$ Considering the manufacturing sectors (defined by NACE codes between 10 and 33, see http: //ec.europa.eu/competition/mergers/cases/index/nace_all.html), the database covers $50 \%$ of firms in France and $92 \%$ of employment in those sectors. 
we remove all firms operating in the real estate, financial and insurance sectors, as well as holding companies. We also exclude firms operating in the public or non-profit sector as well as self-employed entrepreneur. We then drop observations (if any) reporting negative equity or negative total assets as well as observations with an asset/liability mismatches higher than $1 \%$. We only keep firms that have a positive turnover and a positive number of employees. Also, all our variables of interest are truncated at the $99^{\text {th }}$ percentile (and at the $1^{\text {st }}$ in the case where the variable can take negative value) to remove outliers resulting from misreporting. Finally, we also exclude firms for which we have less than 5 consecutive years of reporting.

\subsection{Descriptive statistics}

After imposing all these restrictions, we end up with a sample of roughly 2.31 million of observations, corresponding to almost 177,000 unique firms. The average (resp. median) firm in our sample is 23 years old (resp. 19 years old) and is present in the sample for 13 years (resp. 12 years), with $75 \%$ of them being observed at least 8 years and $25 \%$ of them being observed more than 17 years. In table 1, we provide descriptive statistics about the share among total assets of the main balance sheet items of firms as defined in the section 2.2 . The asset side of the average firm is composed of $24 \%$ of fixed assets (of which $14 \%$ of tangible fixed assets) while the working capital requirements (i.e. the sum of inventories and trade receivables) represent more than $54 \%$ of the total assets. The last sizable category is the cash holdings that amounts to $14 \%$ of total assets of firms. ${ }^{19}$

On the liability side, equity represents the most important financial resource $(34 \%$ of total assets for the average firm). Trade payables are the second most significant items and represent $29 \%$ of total assets on average. Finally, bank credit (12\%) and other financial debts $(8 \%)$ form a rather small share of total liabilities. However, as our analysis will show, the limited importance of bank credit in the balance sheet of firms does not provide direct information about its possible crucial role for the funding of investment. In the figure 1 , we show how the composition of firm balance sheets has evolved over the last 30 years. Finally, in table 2, we provide information about total assets, total sales and total employment of firms in our sample. The median firm in our sample has $€ 1.38$ million of total assets, $€ 2.66$ million of sales and employs 17 workers. In the next paragraph, we examine in more details the distribution of firm size and corporate investment in our sample and how they compare to other studies.

\footnotetext{
${ }^{19}$ The summation of these items can be slighlty different from one as a result of rounding.
} 


\subsection{Firm size and investment}

In this paper, we devote particular attention to the role of firm size in the variation of firm's funding mix, in particular regarding the financing of fixed assets. Indeed, firm size matters for a lot of corporate decisions as evidenced by previous papers: Rajan and Zingales (1995) bring evidence that leverage increases with firm size and Frank and Goyal (2003) showed that pecking order is only found in large firms and Covas and Haan (2011) established that the very largest firms have countercyclical equity and debt issuance while it is procyclical for other firms. More recently, a bunch of papers demonstrated that large and small firms are differentially affected by credit supply shocks (see Chodorow-Reich 2014b) or Cingano et al. (2016) among others).

The literature on corporate finance traditionally decomposes firm size into SMEs, intermediatesized enterprise and large corporations. That decomposition is based on legal and administrative criteria. In this paper, we adopt an alternative perspective and rather use a distributional segmentation of firms in the spirit of Covas and Haan (2011) and Gala and Julio (2016) ${ }^{20}$ This approach has the advantage of being objective regarding the thresholds used to split up firms into segments. It also provides a more detailed picture of SMEs. We follow a quartile decomposition based on total sales of firms. However, to highlight the specific patterns of the very largest firms, the top $25 \%$ of the distribution is further decomposed into sub-segments. The decomposition of firm size Size $^{i}$ is as follows: [p0- p25(, [p25- p50(, [p50- p75(, [p75- p90(, [p90- p95(, [p95-p100]. Importantly this quantile decomposition is time-varying.

In table 3 , we provide information about the distribution of firm size in our sample based on these categories. We measure firm size using the total sales but the picture would be similar if we used the total assets for instance. In this table, we report at different points in time the minimum, the mean and the median value of firm's sales within each size class we use throughout the paper. First, size classes tend to be quite stable over time, with little variation in the minimum, mean and median values within size classes from one decade to another (except for the top $5 \%$ of firms).

Second, our sample covers a population of small and very small firms that are rarely analyzed due to the lack of available data. In 2015, the first quartile of the distribution is made of firms with total sales above $€ 0.75 \mathrm{M}$ and below $€ 1.5 \mathrm{M} .50 \%$ (resp. 90\%) of the firms we study have total sales below $€ 2.77 \mathrm{M}$ (resp. below $€ 20 \mathrm{M}$ ). Comparatively, in Chodorow-Reich (2014b) the median firm has around $\$ 500 \mathrm{M}$ sales, in Gatchev et al. (2010) the average total assets is around $\$ 80 \mathrm{M}$ (against $€ 10 \mathrm{M}$ in our sample) or in Frank and Goyal $(2003)$ the average sales are $\$ 715 \mathrm{M}$, far above the average sales in our sample $(€ 15 \mathrm{M})$. More generally, Lemmon et al. (2008), report that the median non-financial firm in Compustat over the period 1994-2005 has total sales around $\$ 90 \mathrm{M}$, much higher than in our sample

\footnotetext{
${ }^{20}$ On top of that, these categories are elaborated based on consolidated accounts at the group level.
} 
$(€ 2.66 \mathrm{M})$. Finally, Aretz et al. (2020) studies French firms but those above $€ 5$ million sales. By contrast, our sample cover a similar population of firms as Crouzet and Mehrotra (2020) where the average firm has a total assets of $\$ 43 \mathrm{M}$ and on average $\$ 10 \mathrm{M}$ sales. Overall, one contribution of this paper is to shed light on the investment decisions of the population of small and very small firms that we know little about.

However, it is important to acknowledge that these numerous small firms only make a small part of the aggregate investment, sales, assets and employment. In table 4, we present the share of each size class in the cumulative distribution of these variables for the year 2016. We observe that the top $5 \%$ of the largest firms in our sample represents as much as $71 \%$ of the aggregate sales, $60 \%$ of the aggregate bank credit or the aggregate employment and even $80 \%$ of the aggregate investment. To make our estimations consistent with this picture, regressions are also firm size-weighted (see section 2). In table 5, we present the median value of the main balance sheet items (as a fraction of lagged and deflated total assets) within each size class. Only the top $5 \%$ seems to have a significant different balance sheet composition with proportionally more fixed assets and less cash holdings on the assets side and less bank credit, less equity but more trade receivables in the liability side.

We conclude this section with some stylized facts about investment decisions. The table 6 breaks down the frequency of investment decisions as well as the investment rates by size class. The investment frequency increases with firm size: on average, a firm belonging to the bottom $25 \%$ invests once in 3.55 years while a firms belonging to the top $5 \%$ invests once in 2.56 years. This gap is lower when we consider median frequency but remains nonetheless not negligible. By contrast, the magnitude of investment decisions, namely the investment rates computed as the ratio of positive changes in (deflated) net fixed assets over lagged (deflated) fixed assets (as in Clementi and Palazzo (2019) for instance), is decreasing with firm size: from $41 \%$ on average for the bottom $25 \%$, the average investment rate is gradually and monotonically reduced and drops to $23 \%$ for the top $5 \%$ largest firms. This pattern as well as the level of the average investment rates are consistent with the findings established by Gala and Julio (2016) showing that "firm size is at least as important as Tobin's $Q$ and cash flow, both economically and statistically, in explaining variation in corporate investments". To summarize, larger firms tends to invest more frequently but proportionnally less relative to their initial stock of capital. 


\section{Empirical results}

\subsection{How do firms finance their fixed asset and working capital asset investment?}

We start by examining in a very general way to what extent variations in fixed assets and working capital assets are associated with systematic changes in the liability components of the balance sheet of firms. The table 7 reports the results from the unweighted estimation of the equation (9) presented in the section 2.2. Each column correspond to the flow of one of the $k$ funding sources described in equation (8), namely: equity, retained earnings, bank credit, cash holdings, other financial debts and residual liabilities. As explained in the section 2.1, the $k$ estimated coefficients of a given assets to fund must sum up to one across all the sources of funds: $\sum_{k} \beta^{k}=1$. The parameters estimated under this very simple framework provide first insights on the distinct role played by each of these financial resources in the funding of fixed asset and working capital asset investment.

First, despite its rather limited importance in the balance sheet of firms (12\% of total assets, see 3.2), bank credit emerges as the predominant financing sources of fixed assets investment (roughly 58\%). Then, other financial debts, retained earnings and cash holdings ${ }^{21}$ are the next sources of funding associated with investment, each of them contributing to more or less $10 \%$ of the financing of variations in fixed assets. The role of equity financing seems very marginal at this stage while the contribution of residual liabilities, mostly composed of tax and social debts, is limited. By contrast, the financing of working capital assets is more balanced: cash holdings is estimated to be the primary source of funds used (34\%), followed by bank credit (19\%), retained earnings (16\%) and other financial debts (13\%). The contribution of equity to the financing of inventories and net trade credit appears to be negligible.

In table 8 , we estimate the same specifications as in table 7 but we now the estimation is firm size-weighted. Firm size is based on total sales. The financing patterns depicted in this table are significantly different. Regarding the financing of fixed assets investment, the role of bank credit is lowered by one third to $38 \%$ while the contribution of other financial debts and equity are strongly revised upward to $22 \%$ and $8 \%$ respectively. In the case of working capital assets investment, the estimated financing mix appears more proportionate once we take into consideration firm size heterogeneity through weightedOLS: the role of cash holding is now of the same order of magnitude as the role of other financial debts (around 20\%-25\%) whereas the contribution of other funding sources remains

\footnotetext{
${ }^{21}$ The estimated coefficient associated with cash holdings is negative. This comes from the fact that a use of cash correspond to a decrease in cash holdings. As we consider cash holdings as a funding source (see the balance sheet identity 8), its contribution is obtained by taking the inverse of the (negative) estimated coefficient. This convention is valid all along the paper.
} 
more or less unchanged 2 . The differences in the financing patterns emerging from weighted and unweighted estimations are first evidence that small and large firms do not finance their fixed assets and working capital requirements in the same ways, as we will investigate in depth later on.

How do these results compare with the literature? The closest investigation to ours is Gatchev et al. (2009) but, given their focus on the role of cash flow as well as the fact that they generally do not distinguish between bank debts and other debts (but rather between short-term debts and long-term debts), the comparison is not straightforward. On top of that, accounting rules are not the same across the US and France and that pose additional difficulties. That being said, Gatchev et al. (2009) found that "when financing a dollar of investment in net fixed assets the average firm relies on \$0.19 of short-term debt, \$0.51 of long term borrowings, and \$0.39 of equity" while "when financing a dollar of investment in net working assets, the average firm borrows \$0.17 of short-term debt, borrows \$0.12 of long-term debt, and issues \$0.72 of equity.". Hence, if we adopt a dichotomy debt/equity, irrespective of the type and maturiy of debts, we observe that the average US firms tends to finance one dollar of fixed assets investment with $39 \%$ of equity and $70 \%$ of debts while a typical French firm finances one euro of additionnal fixed assets investment using only $8.5 \%$ of equity and $60 \%$ of debts 23 Regarding the financing of working capital investment, we estimate the respective contributions of debts and equity to be $46 \%$ and $4 \%$. At the same time, French firms use much more cash holdings (almost 25\%) than their US counterpart to finance fluctuations in inventories and trade receivables.

Unfortunately, we cannot go further in the comparison but we still observe that the main difference comes from the crucial role of equity finance in the US which is found to be seven times larger than in France in the case of fixed assets investment and even more in the case of working capital assets. Although the methodology and the accounting rules differ across the two papers, the gap is so large that this discrepancy in the role of equity finance must be considered as a strong empirical evidence. The different contribution of equity funding between France and the US is entirely consistent with narrative evidence on the differences between US and continental EU regarding the role and the developpement of securities markets (bank-based vs. market-based financial systems, see Levine (2002)): for instance, it is estimated that "the value of corporate bond and stock markets as \% of GDP equals $12 \%$ and $56 \%$ for the EU (10\% and 51\% for EU27, respectively), compared to $31 \%$ and 112\% for the US." (SMSG, 2017). Our results are also consistent with the findings of Carluccio et al. (2019) who identify a limited impact of the cost of equity on investment

\footnotetext{
${ }^{22}$ If the contribution of equity financing remains very marginal (around 4\%), we nonetheless observe that it is more than 4 times higher than previously estimated (less than 1\%)

${ }^{23}$ In Gatchev et al. (2009), the summation of the estimated contributions is ensured because they find a negative contribution of cash holdings (-8\%). In our case, the remaining $31.5 \%$ to finance comes from retained earnings $(11 \%)$, cash holding $(9 \%)$ and residual liabilities $(11.5 \%)$.
} 
decisions on French firms (in contrast with Frank and Shen (2016) who find a significant effect for the US firms).

\subsection{To what extent firm size affects the financing of investment?}

We now investigate how the financing of investment interacts with firm size. We first explained in the section 3.3 why firm size may have a substantial impact on important corporate decisions (leverage dynamics, reactions to credit supply shocks and cyclicality in particular). Moreover, the differences in the results from weighted and unweighted estimations have already provided indirect evidence that firm size matters for financing patterns.

Against this background, we now explore to what extent the financing of investment vary along firm size. Indeed, it has long been established that small and large firms differs a lot in terms of both asymmetry of information, diversification and access to capital markets (due to transaction costs). As a results, the pecking order theory as well as other capital structure theories have different consequences for small and large firms (Frank and Goyal 2003 and De Jong et al. 2008). We thus expect to find significantly different patterns for small and large firms in terms of financing mix. Notably, we expect to observe that large firms finance a larger share of their investment using market securities and a smaller share using bank debts or internal financial resources.

For this purpose, we use a size decomposition based on quantiles of firm's total sales $S i z e^{i}$ (see 3.3 for more details about these size buckets). We then enrich our specification (9) by interacting dummy variables associated with each quantile of firm size Size ${ }^{i}$ with the dependent variables: 24

$$
\begin{aligned}
\Delta Y_{t}^{k}= & \alpha^{k}+\sum_{i} \beta_{i}^{k} \cdot \Delta F A_{f, t} \cdot S i z e_{f, t}^{i}+\sum_{i} \gamma_{i}^{k} \cdot \Delta W C A_{f, t} \cdot S i z e_{f, t}^{i} \\
& \sum_{i} \omega_{i}^{k} \cdot \Delta R A_{f, t} \cdot S i z e_{f, t}^{i}+\sum_{i} \omega_{i} \cdot S i z e_{f, t}^{i}+\epsilon_{f, t}^{k} \text { if } \Delta F A_{f, t}>0
\end{aligned}
$$

We report the results from these regressions in tables 9 and 10 . For the sake of readibility, we only report the coefficients $\left\{\hat{\beta}_{i}^{k}\right\}$ and $\left\{\hat{\gamma}_{i}^{k}\right\}$ and we omit the coefficient associated with residual liabilities. The results bring out a clear distinction in the way firms finance their investment depending on their size.

First, we observe a monotonic and decreasing relationship between firm size and the contribution of bank credit to the financing of investment: from $63 \%$ for the bottom $25 \%$ of the firm size distribution, the contribution of bank credit diminishes to $39 \%$ in the unweighted regressions (and even 25\% in the case of weighted regressions) for the very largest firms (top $5 \%$ ). The reduction is rather slow at the begining of the distribution but accelerate significantly starting from the last decile. The most important contrast is between the top $5 \%$

\footnotetext{
${ }^{24}$ We could as well run separated regressions for each size class but the results would be entirely the same
} 
and the rest of the distribution. This contrast is accentuated when regressions are weighted by firm size (10) given the much higher degree of heterogeneity in firm size within the top $5 \%$. Overall, as we consider firms of larger size, we find that the role of bank credit in the financing of investment become increasingly less important.

Since the estimated parameters must sum up to one, the contributions coming from other sources of funding must increase as we move across higher quantiles to offset the decreasing trend observed in the contribution of bank credit. In both tables, we observe that the contribution of other financial debts increases monotonically with firm size: from $8 \%$ for the bottom $25 \%$, it reaches between $23 \%$ and $29 \%$ for the top $5 \%$ of the distribution of firm size. The same trend is observable for equity financing. Its contribution moves from almost zero for the bottom $25 \%$ to $8 \%$ for the top $5 \%$ when the regressions are not weighted (and even 13\% when they are). The discrepancy between the weighted and the unweighted regressions comes from the high degree of heterogeneity within the top 5\%. As a result, the important contribution of equity funding to the financing of investment of the very largest firms is obscured when the regressions are not weighted by firm size. Finally, the role of retained earnings and cash holdings in the financing of fixed assets investment is largely constant across firm size in both types of specifications.

These findings are largely consistent with what we know about the way firm size is likely to interact with financing decisions. First, it is common knowledge that size matters a lot regarding the access to some financial instruments. Bond and equity markets are not easily accessible to SMEs because of transaction costs that could discourage firms to issue securities. Small firms also suffer a higher degree of information asymmetry (due to a higher opaqueness in particular) and, as a results, they face higher costs when issuing informationally sensitive securities like equity (Rajan and Zingales, 1995). On top of that, small firms have less often an external credit rating than large firm. Consistent with that view, the $21^{\text {st }}$ round of the ECB Survey on the Access to Finance of Enterprises (SAFE) covering the period from April to September 2019 indicates that market-based sources of finance such as equity and debt securities only account for respectively $11 \%$ and $4 \%$ of the total funding of SMEs (against 50\% for bank loan and bank credit line). These figures are in line with our estimated contributions.

However, the relation between firm size and the funding of fixed assets investment seems to differ significantly between US and French firms. While we find that large firms use less bank credit and more equity, Gatchev et al. (2009) find that "firm size is inversely related to the proportion of fixed assets financed through equity", in contrast with the pecking order theory if we assume that small firms are presumably informationally less transparent. Otherwise, Beck et al. (2008) use a firm-level survey database and show that "smaller firms finance a lower proportion of their investment externally, in particular because they make use of bank finance to a lesser extent". Our results do not support this statement. We rather observe that the role of bank credit is increasingly important for the smallest firms. The 
differences may come from the fact that, as indicated by the authors, "the survey data have a selection bias because respondents are not necessarily a representative sample of firms from their countries". On top of that, they only get information from 33 firms for France what limits the external validity of their findings. Finally, in a recent paper, Gala and Julio (2016) show that a firm's investment rate is inversely related to its size, even after controlling for common factors, like Tobin's Q and cash flow among others. Our findings provide a relevant complement to this paper by quantifying how the financing of investment is also changing with firm size.

Regarding the financing of the working capital assets investment, we just take note of the decreasing role of cash holding and an increasing role of other financial debts as we consider larger and larger firms. At the same time, other funding sources seem to be largely unaffected by firm size. This finding is equally consistent with a view where larger firms have an easier access to financial markets and rely thus less on internal source of funds like cash holdings to finance their inventories and trade payables.

\subsection{Tangible vs intangible assets: does the nature of investment matters for the funding mix?}

In the section 4.1, we have established the fundamental role of bank credit when it comes to invest in new fixed assets. Until now, we have considered total fixed assets, irrespective of their nature. Yet, the nature of investment has strongly changed over the last twenty years: the rise of intangible assets isn one of the most prominent economic phenomenon (Haskel and Westlake, 2018). As a consequence, both the measurement and the effectiveness of investment are intensively questionned by economists (Corrado et al., 2009, Peters and Taylor, 2017). Part of the lack of investment observed these last years could be related to the difficulty to properly assess intangible investment, especially R\&D and SG\&A expenditures that cannot be easily capitalized under some accounting rules. Additionally, it is generally admitted that the lack of tangibility of immaterial assets resulting from its low redeployability, nonexclusiveness, and low liquidity Hall and Lerner (2010) can act as a credit constraint by limiting the ability of firms to pledge collateral against external borrowing (Rampini and Viswanathan, 2013, Borisova and Brown, 2013). For instance, Falato et al. (2018) establish that the rise in intangible capital is a fundamental driver of the secular increasing trend in US corporate cash holdings over the last decades by shrinking the debt capacity of firms.

In our data, we could distinguish between tangible and intangible fixed assets (as well as financial assets that are of less interest however). Tangible fixed assets are composed of proprerty, plants and equipment. By contrast, intangible fixed assets are made of goodwills, capitalized R\&D expenditures, patents, licences and set-up costs. This balance sheet item nonetheless misses important parts of intangible capital like SG\&A or training expenditures. We nonetheless apply the same econometric setting as previously but we now distinguish 
between tangible and intangible fixed assets. The results from this augmented specification can be found in table 11 (unweighted OLS) and 12 (weighted OLS).

Not surprisingly, we observe significant differences in the financing mix of tangible and intangible fixed assets. First, when we do not use weights in our estimations, the contribution of bank credit to the funding of investment is strongly larger in the case of tangible investment $(60 \%)$ than it is for intangible investment (43\%). In turn, the contribution of other financial debts and equity are much larger for intangible investment (resp. 26\% and $10 \%$ ) than it is for tangible investment (resp. $9 \%$ and less than 1\%). In contrast, retained earnings only have a role in the financing of tangible investment $(10 \%$ against $0 \%$ in the case of intangible investment). We also measure negligible differences in the role of cash holdings.

If we turn to the weighted estimations presented in table 12 , we continue to observe the same differences: for instance, the contribution of bank credit is almost twice larger in the case of tangible investment than it is for intangible investment (44\% vs 23\%), a discrepancy of the same order of magnitude as in Gatchev et al. (2009). Note however that the overall level of this contribution is smaller across both types of investment as compared to unweighted estimated parameters. While the contribution of other financial debts to the financing of intangible investment is more or less the same in both types of estimation, the contribution of equity finance rises strongly when we use weighted regressions. In the case of intangible investment, the role of equity is no longer marginal at all: its contribution (17\%) is now just slightly lower than that of bank credit (23\%).

Interestingly, the role of retained earnings is zero and the contribution of residual liabilities is significantly higher than otherwise. To understand this last finding, note that the residual liabilities component is largely made of tax and social security debts (up to $80 \%$ on average). Yet, there exist in France an important and longstanding tax credit on R\&D and innovation. As explained by Bozio et al. (2014), "in 2011, 17,000 firms took advantage of the scheme, and it is estimated to cost $€ 3.07$ billion in tax expenditures" and "declared RED spending qualifying for the tax credit amounted to $€ 18$. 2 billion.". This could explain why the role of residual liabilities suddenly pops up in the decomposition of the financing of intangible investment.

The main conclusions from this section are the following. First, bank credit remains the first and most importance financial resource to undertake tangible investment, even if its contribution decreases once we take into account firm size heterogeneity. Regarding the financing of intangible investment, the financing mix is much more balanced across various sources: bank credit no longer emerges as the first financing source. Importantly, the role of equity funding becomes sizable when it comes to finance immaterial assets as shown for US firms by Gatchev et al. (2009). These findings are consistent with a view where tangibility is making assets pledgeable (Almeida and Campello, 2007). Indeed, intangible investments are not only hard to measure but also hard to collaterize against credit and this 
could explain why equity funding is more intense in the financing of $R \& D$ expenditures and software development for instance.

\subsection{Does the funding mix varies along the size of investment?}

In this section, we examine a plausible, mostly ignored but probably important source of heterogeneity in the financing mix of firms: the size of the investment undertaken. Surprisingly, this dimension has only rarely been investigated in corporate finance. To the best of our knowledge, Chay et al. (2015) and Elsas et al. (2013) are the only papers studying to what extent small and large investments imply different financial choices from firms.

Why should the financing of large and small investments differ? First, small and large investments differ significantly in terms of collateralization: large investments in machinery, lands or buildings are much more pledgeable than smaller investments (in furniture and fixtures or computer equipment for instance) because machinery and buildings have a slower depreciation and liquid secondary markets. All in all, large investments are more prone to collateralization and, as a result, these large investments are presumably less financially constrained (Gan, 2007; Almeida and Campello, 2007). Moreover, as explained by Chay et al. (2015), large investments are more likely to exhaust internal funds available, pushing to resort more frequently to external funding. Finally, it could also be that small investments are more frequent and more idiosyncrati 25 making more likely to fund them with internal financial resources immediatly available.

To explore this question, we enrich our baseline specification (9). We compute the median of the investment to assets ratio, i.e. the median of the changes in fixed assets over total assets, within each year ${ }^{26}$ Then, we classify each of the investment decision into a large/small classification depending on whether the size of the investment undertaken is higher or lower than this yearly median value. ${ }^{27}$ Finally, we interact the dummy variables Small $_{f, t}$ and Large $_{f, t}$ classifying investments according to their relative size with our main depend variable:

$$
\begin{aligned}
\Delta Y_{t}^{k}= & \alpha^{k}+\beta_{\text {Large }}^{k} \cdot \Delta F A_{f, t} \cdot \operatorname{Large}_{f, t}+\beta_{\text {Small }^{k}} \cdot \Delta F A_{f, t} \cdot \operatorname{Small}_{f, t} \\
& +\gamma^{k} \cdot \Delta W C A_{f, t}+\omega^{k} \cdot \Delta R A_{f, t}+\operatorname{Large}_{f, t}+\epsilon_{f, t}^{k} \text { if } \Delta F A_{f, t}>0
\end{aligned}
$$

\footnotetext{
${ }^{25}$ We indeed observe in our data that what we classify as large investments are slightly more frequent than small investments. Firms tend to make a small investments once every 2.8 years against once every 2.3 years for a large investments.

${ }^{26}$ Comparing large and small investments in absolute value would be largely irrelevant as we would mainly capture differences in firm size examined previously.

${ }^{27} \mathrm{We}$ could define small and large investments in different ways. We could for instance compute the median investment size over the entire period under study or alternatively within a given business sector. All in all, our results are largely robust to these alternative definitions of small and large investments. Results available upon request.
} 
Graphical evidence Before presenting the results, we first provide an intuition of our findings. In the figure 2, we plot the average change in bank credit (scaled by lagged and deflated total assets) within each percentile of the distribution of the positive changes in fixed assets (scaled by lagged and deflated total assets). We also represent the median of this investment variable over the entire sample as well as two regression lines fitted over the two samples (above/below the median investment). In this graph, the steepness of the two regression lines are more or less the estimated parameters $\hat{\beta}_{\text {Large }}^{\text {Bankredit }}$ and $\hat{\beta}_{\text {Small }}^{\text {Bankredit }}$ in the specification (11). While it is not highly visible due to the scale of the x-axis, these two fitted lines have significantly different slopes.

This graphical representation considers both the extensive and the intensive margins at the same time and it is interesting to decompose further this relation between investment and bank credit into these two margins. This is what we do in the figures 3 and 4 . In the first one, we show the extensive margin, i.e. the proportion of firms that relies on bank credit when they invest while in the second one, we show the intensive margin, i.e. the intensity of the relationship between investment and bank credit, conditional on using bank credit.

Regarding the extensive margin, we observe an unambiguous concave relationship: as we consider investment of larger (relative) size, the propensity to use bank credit increases significantly but at a decreasing rate. Once we abstract from this relation at the extensive margin, the relation at the intensive margin represented in the figure 4 points out to much larger differences in the use of bank credit depending on investment size: below the median investment, investments are less bank-credit intensive, while above the median investment, investments are much more bank credit intensive. To confirm and generalize this observation that financing patterns (bank credit in this case) vary significantly with the relative size of investments, we now move to the more formal regression analysis explained just above.

Regression results The results from regressions specified in equation (11) are in table 13 (unweighted OLS) and 14 (weighted OLS). It appears clearly that the funding mix associated with small and large investments decisions differs significantly. Bank credit seems much more relevant for the financing of large investments: in the unweighted regressions, the contribution of bank credit is 13 percentage points larger for investments above the median than it is for investments below the median (61\% vs $48 \%$ ). This is entirely consistent with the graphical evidence presented in the previous paragraph. The difference in the estimated contribution of bank credit for large and small investments from the weighted regressions is even larger in absolute value: large investments require 16 percentages points more bank credit than small investments. By contrast, we find only small or less significant differences in the use of other financial debts and equity to fund investment expenditures.

One of the most striking results we uncover is definitely the contribution of retained earnings to the financing of investment. Whether we use weights or not in our regressions, 
the estimated contribution of this internal source of funds is very signficant in the case of small investments and only marginal in the case of large investments. In the weigthed regressions, its estimated contribution is even as large as for bank credit (28\% against $30 \%$ ). This huge discrepancy in the role of internal source of funds between large and small investments is fully consistent with the findings of Chay et al. (2015) "that external funds play a greater role than internal funds do at high levels of investments, reflecting the limited availability of internal funds.". The role of cash holding is not very clear, especially across the two sets of regressions, but overall it seems to be only a marginal source of funding in both cases.

We go one step further by decomposing the large investments into two subgroups: investments above the yearly median investment and below the $90^{t h}$ percentile of the distribution of investments (that we denote as middle-sized investments) and investments above the $90^{\text {th }}$ percentile of the distribution of investments (that we now identify as the large investments). We presents these results in table 15 (unweighted) and 16 (weighted). This confirms the patterns that we just identified: firms increasingly use bank credit when it comes to finance larger and larger investment while the role of internal funding tends to decrease as we consider larger and larger firms. No specific and consistent patterns are observed regarding the other funding sources however. In general, external finance (bank credit, other financial debts and equity) contributes to finance between $70 \%$ and $80 \%$ of large investments according to our estimation. This is in line with Elsas et al. (2013) that indicate that mean US firm finances $67 \%$ of its major investments (identified as investments larger than $30 \%$ of total assets of the firm) with externally raised funds. But, in contrast with Elsas et al. (2013) we find a much more limited role of equity funding.

However, it is possible that large investments are more often tangible investments, such that tangibility and investment size could be confused. This is why we replicate the results by distinguishing tangible and intangible investments. We now define small and large investments for both tangible and intangible fixed assets. The results can be found in table 17 and 18 in appendix 9.2 and they largely confirm the main conclusions of this section: large investments decisions are funded primarily through bank credit (50\% to $60 \%$ in the case of tangible investment against $20 \%$ to $40 \%$ in the case of intangible investments) while small investments decisions rely extensively on retained earnings (around 30\%, that is, more than bank credit in the weighted regressions).

To finish our investigation, we examine how firm size and investment size interplay with each other in the financing of fixed assets investment: does the financing mix of large and small firms differ for both small and large investments decisions? To answer this question, we replicate the specification 10$\}$ and estimate each size-related coefficient $\left\{\hat{\beta}_{i}^{k}\right\}$ for small and large investments. The results can be found in tables 19 (unweighted) and 20 (weighted) in appendix. We continue to observe a decreasing contribution of bank credit to fixed assets investment for both large and small investments and for both weighted and 
unweighted estimations. The decreasing trend is nonetheless much marked in the case of large investments. At the same time, the overall level of the contribution of bank credit for each size class is systematically higher for large investments decisions than for small investments decisions. However, the discrepancy between large and small investments is reduced as we consider larger firms. Finally, the results indicates that small investments decisions are mainly financed using bank credit and cash holdings in the case of small firms while it is mainly financed through bank credit and retained earnings when we consider large firms. Overall, the main findings uncovered during this empirical investigation can be summarized as follow: (i) firm size continues to matter for the financing of investment once we consider separately small and large investments, albeit more for large investments, (ii) large and small investments show distinct financing mix, even within each size class and (iii) the contribution of internal finance like retained earnings and cash holdings is more related to the size of the investment undetaken than to the size of the firms.

\subsection{How does our estimated contributions have fluctuated over the last twenty years?}

Before turning to some robustness tests, we examine how the funding mix of firms has fluctuated over time. Indeed, these last twenty years, the financial markets have deeply evolved. In particular, the wave of disintermediation and deregulation that occured before 2008 has been largely documented. As a result, the availability and the diversity of financial instruments has considerably grown. More recently, the ongoing Fintech revolution could transform the funding mix of many firms. Overall, there are important motives to consider that the funding of fixed assets investment is likely to have significantly changed these last years. In this case, we should observe trends in the contribution of various sources of funding and we investigate it in this section.

For this purpose, we reestimate the specification (9) but we now interact each of the $k$ funding sources with dummy variables for years. The results from these regressions can be found in the figure 5 where we report the four-periods moving average of the estimated coefficient for each funding sources. For the sake of readibility, we omit the confidence bands. The picture is striking in the sense that the contributions of the various funding sources are remarkably stable over the last twenty years. We observe small fluctuations from one year to another, but overall, the contributions of these funding sources are largely the same in the last decade as they were in the 90's. If we look very carefully, we could note a slight upward trend in the contribution of bank credit at the end of the 90's as well as a kind a substitution between retained earnings and other financial debts starting from 2007. The decrease in the contribution of retained earnings between 2007 and 2013 corresponds to the period where the French economy was hit and still recover from both the Great Financial crisis and the Eurozone crisis and this decrease may be related to the lack of profitability of 
French firms during this period (Bauer and Boussard, 2019).

\subsection{Robustness checks}

Intertemporal dependencies in financing and investment decisions In our conceptual framework, we relate changes in fixed assets and working capital assets with changes in liability components at a given period. However, in practice, firms make dynamic decisions based on intertemporall trade-off. For instance, a firm can raise funds by issuing bonds or equity at a certain period given the advantageous market conditions and use the funds to invest later on. These last years, with the persistent very low interest rates, we have seen firms issuing debt at very low costs and simultaneously holdings an increasing amount of cash. We thus follow Gatchev et al. (2010) and include lagged dependent variables in our weighted specifications (see equation $(9 p)$ in order to take into account the intertemporal dependencies in investment and financing decisions. Results can be found in table 21 in appendix. In contrast with Gatchev et al. (2010), the inclusion of lagged dependent variables has a very limited impact on our estimated coefficients of interest that are very similar to those in table 11. Note also that we observe persistence in equity, retained earnings as well as cash holdings while bank credit and other financial debts are rather characterized by mean reversion. We also estimate a richer structure by including additional lags and we still observe only marginal changes in the estimated coefficients. Overall, inter-temporal dependencies do not seem to affect our main conclusions.

\section{Alternative samples of firms: independent firms, firms accessing to bank credit} and firms with disinvestment decisions All our results have been established on a sample made of firms reporting their financial statements at the legal unit level and having a positive change in fixed assets. However, we know that internal capital markets and business group relationships matter, especially in terms of funding. Unfortunately, we do not have a dataset reporting consolidated financial statements of firms. However, we have an information in our dataset that make possible to restrict our sample to independent firms (as in Kremp and Sevestre 2013). By doing so, we exclude any intra-group financial relationships from our estimation. We thus rerun the weighted regressions on this sample and the results can be found in table 22 in appendix. As we can see, the main conclusion remains entirely valid on this sample. We nonetheless observe that the estimated parameters for bank credit are higher and those for other financial debts and equity lower. Indeed, the sample of independent firms is made of smaller firms and thus these differences are entirely consistent with our findings regarding the effect of size on the funding mix of firms.

We also reestimate our parameters of interest on two alternative samples. First, we impose that firms have positive amount of bank credit. Conditionning on the availability of bank credit is a way to explore the robustness of our results on a sample of firms that 
are presumably less financially constrained than otherwise. Second, we relax the restriction imposing to observe a positive change in fixed assets in order to include disinvestment decisions in our estimations. Results on these alternative samples can be found in table 23 and 24. We observe small variations in the estimated coefficients, but overall, our conclusions are robust to these alternative samples.

Alternative measure of investment In the results presented until now, we only measure indirectly the investment made by firms: it is computed as the positive changes in fixed assets. The main reason for using this measure is to ensure the consistency of our estimate by preserving the underlying balance sheet identity. Otherwise, we could no longer interpret our paramaters of interest as the estimated contribution of each funding source to the financing of investment (see the section 2 presenting the conceptual framework we use). That being said, we could nonetheless relax this requirement and use a more consistent measure of investment: the net acquisition of fixed assets. Since the balance sheet identity is now violated, the estimated coefficient cannot be directly compared to the previous one. However, the estimated differences between the financing mix of large and small investments remain comparable to the same differences estimated using our baseline balance sheet identity and presented in table 14. We present the results from this test using the acquisition of fixed assets as our investment variable in table 25 in appendix. The conclusions drawn from the section 4.4 remain true: firms tend to use more bank credit to finance large investments than small investments while they also tend to use more internal resources, i.e. retained earnings, to finance small investments than large investments.

\section{Concluding remarks}

In this paper we investigate to what extent different funding sources (bank credit, financial debts, equity, retained earnings and cash holdings) contribute to finance both fixed assets and working capital assets accumulation. Our study also examine to what extent these financing patterns are likely to vary with the nature of assets to fund (tangible vs. intangible assets), the size of the firms and the size of the investments undertaken.

Our findings are the following. First, bank credit appears critical to the financing of investment for the vast majority of firms: we estimate its contribution to the financing of fixed assets accumulation to be around $60 \%$. The remaining funding sources are (i) the other financial debts, (ii) the retained earnings and (iii) the cash holdings and each of them contributes to more or less $10 \%$ of the financing needs.

We then find that, the contribution of bank credit to fixed assets investment strongly decreases as we consider larger firms: from $60 \%$ for the bottom $25 \%$ of the distribution of firm size, the contribution of bank credit is estimated to be only $40 \%$ for the top $5 \%$ 
largest firms. At the same time, the contribution of other financial debts and equity funding are found to be largely increasing with firm size. As a result, larger firms are much less dependent on bank credit when it comes to invest in new fixed assets and they make use of alternative financial instruments like bonds and equity to cover the remaining funding needs. In contrast, we find that the contribution of bank credit to fund working capital assets is rather independent on firm size (around 19\%).

Third, bank credit strongly contributes to the funding of tangible fixed assets $(43 \%$ in the weighted-OLS estimation) but to a lower extent to the funding of intangible fixed assets $(23 \%)$. Indeed, intangible fixed assets rely proportionally more on equity ( $17 \%$ for intangible fixed assets vs $7 \%$ for tangible fixed assets) and other financial debts (30\% vs $20 \%$ ). Retained earning and cash holdings play no significant role in the funding of intangible fixed assets.

Finally, we show that the funding mix also changes significantly depending on the size of investments undertaken. Bank credit strongly contributes to fund large investments ( $46 \%$ of large investments) but much less to fund small investments (30\%). On the contrary internal financial resources, and most notably retained earnings, emerge as an important source to finance small investments.

Those results are quite stable over time and raise questions both for policy makers and for future research that goes beyond the scope of this work. In particular, to what extent Fintechs and innovation in the financial sector will change those funding patterns, in particular regarding the funding of the working capital assets, where bank credit plays a smaller role? How policy makers can ease the external funding of intangible fixed assets? 


\section{Bibliography}

Acharya, V. V. and G. Plantin (2019, November). Monetary easing, leveraged payouts and lack of investment. Working Paper 26471, National Bureau of Economic Research.

Alexander, L. and J. Eberly (2018, March). Investment Hollowing Out. IMF Economic Review 66(1), 5-30.

Almeida, H. and M. Campello (2007, 04). Financial Constraints, Asset Tangibility, and Corporate Investment. The Review of Financial Studies 20(5), 1429-1460.

Aretz, K., M. Campello, and M.-T. Marchica (2020). Access to collateral and the democratization of credit: France's reform of the napoleonic security code. The Journal of Finance 75 (1), 45-90.

Banerjee, R. N., J. Kearns, and M. J. Lombardi (2015, March). (Why) Is investment weak? BIS Quarterly Review.

Bauer, A. and J. Boussard (2019, November). Market Power and Labor Share. working paper or preprint.

Beck, T., A. Demirgüç-Kunt, and V. Maksimovic (2008). Financing patterns around the world: Are small firms different? Journal of Financial Economics 89(3), 467 - 487.

Beck, T., A. Demirguç-Kunt, L. Laeven, and R. Levine (2008). Finance, firm size, and growth. Journal of Money, Credit and Banking 40(7), 1379-1405.

Beck, T. and A. Demirguc-Kunt (2006). Small and medium-size enterprises: Access to finance as a growth constraint. Journal of Banking \& Finance 30(11), 2931 - 2943.

Bernard, A., E. Dhyne, G. Magerman, K. Manova, and A. Moxnes (2019). The origins of firm heterogeneity: A production network approach. CEPR Discussion Papers 13429, C.E.P.R. Discussion Papers.

Bernard, A. B., J. B. Jensen, S. J. Redding, and P. K. Schott (2007, September). Firms in international trade. Journal of Economic Perspectives 21(3), 105-130.

Borisova, G. and J. R. Brown (2013). R\&d sensitivity to asset sale proceeds: New evidence on financing constraints and intangible investment. Journal of Banking \& Finance 37(1), $159-173$.

Bozio, A., D. Irac, and L. Py (2014). Impact of research tax credit on R\&D and innovation: evidence from the 2008 French reform. Technical report.

Carluccio, J., C. Mazet-Sonilhac, and J.-S. Mésonnier (2019). Investment and the wacc: new micro evidence for france. Working papers, Banque de France. 
Cerqueiro, G., S. Ongena, and K. Roszbach (2019). Collateral damaged? priority structure, credit supply, and firm performance. Journal of Financial Intermediation, 100824.

Chaney, T., D. Sraer, and D. Thesmar (2012, May). The collateral channel: How real estate shocks affect corporate investment. American Economic Review 102(6), 2381-2409.

Chay, J., S. H. Park, S. Kim, and J. Suh (2015). Financing hierarchy: Evidence from quantile regression. Journal of Corporate Finance 33, 147 - 163.

Chodorow-Reich, G. (2014a). The employment effects of credit market disruptions: Firmlevel evidence from the 2008-9 financial crisis *. The Quarterly Journal of Economics 129(1), 1-59.

Chodorow-Reich, G. (2014b). The Employment Effects of Credit Market Disruptions: Firm-level Evidence from the 2008-9 Financial Crisis. The Quarterly Journal of Economics 129(1), 1-59.

Cingano, F., F. Manaresi, and E. Sette (2016, 06). Does Credit Crunch Investment Down? New Evidence on the Real Effects of the Bank-Lending Channel. The Review of Financial Studies 29(10), 2737-2773.

Clementi, G. L. and B. Palazzo (2019). Investment and the cross-section of equity returns. The Journal of Finance $74(1), 281-321$.

Corrado, C., C. Hulten, and D. Sichel (2009). Intangible capital and us economic growth. Review of income and wealth 55(3), 661-685.

Covas, F. and W. J. D. Haan (2011, April). The Cyclical Behavior of Debt and Equity Finance. American Economic Review 101(2), 877-899.

Crouzet, N. and N. R. Mehrotra (2020, February). Small and Large Firms Over the Business Cycle. Working Papers 18-09, Center for Economic Studies, U.S. Census Bureau.

Dasgupta, S., T. H. Noe, and Z. Wang (2011, November). Where Did All the Dollars Go? The Effect of Cash Flows on Capital and Asset Structure. Journal of Financial and Quantitative Analysis 46(05), 1259-1294.

De Jong, A., R. Kabir, and T. T. Nguyen (2008). Capital structure around the world: The roles of firm-and country-specific determinants. Journal of Banking 63 Finance 32(9), 1954-1969.

Disney, R., H. Miller, and T. Pope (2020). Firm-level investment spikes and aggregate investment over the great recession. Economica 87(345), 217-248.

Eaton, J., S. Kortum, and F. Kramarz (2004, May). Dissecting Trade: Firms, Industries, and Export Destinations. American Economic Review 94(2), 150-154. 
Elsas, R., M. J. Flannery, and J. A. Garfinkel (2013, 08). Financing Major Investments: Information about Capital Structure Decisions. Review of Finance 18(4), 1341-1386.

Falato, A., D. Kadyrzhanova, J. Sim, and R. Steri (2018, 01). Rising intangible capital, shrinking debt capacity, and the us corporate savings glut. SSRN Electronic Journal.

Fay, R., J.-D. Guénette, M. Leduc, and L. Morel (2017). Why Is Global Business Investment So Weak? Some Insights from Advanced Economies. Bank of Canada Review 2017(Spring), 56-67.

Fazzari, S. M., R. G. Hubbard, B. C. Petersen, A. S. Blinder, and J. M. Poterba (1988). Financing constraints and corporate investment. Brookings papers on economic activity 1988(1), 141-206.

Frank, M. Z. and V. K. Goyal (2003, February). Testing the pecking order theory of capital structure. Journal of Financial Economics 67(2), 217-248.

Frank, M. Z. and T. Shen (2016). Investment and the weighted average cost of capital. Journal of Financial Economics 119(2), 300-315.

Gabaix, X. (2009). Power laws in economics and finance. Annual Review of Economics 1(1), $255-294$.

Gala, V. and B. Julio (2016, 09). Firm size and corporate investment. Working paper.

Gan, J. (2007). Collateral, debt capacity, and corporate investment: Evidence from a natural experiment. Journal of Financial Economics 85(3), 709 - 734.

Gatchev, V. A., T. Pulvino, and V. Tarhan (2010, April). The Interdependent and Intertemporal Nature of Financial Decisions: An Application to Cash Flow Sensitivities. Journal of Finance 65(2), 725-763.

Gatchev, V. A., P. A. Spindt, and V. Tarhan (2009, April). How do firms finance their investments?: The relative importance of equity issuance and debt contracting costs. Journal of Corporate Finance 15(2), 179-195.

Gertler, M. and S. Gilchrist (1994). Monetary policy, business cycles, and the behavior of small manufacturing firms. The Quarterly Journal of Economics 109(2), 309-340.

Gordon, R. J. (2016). The Rise and Fall of American Growth: The U.S. Standard of Living since the Civil War (1 ed.). Princeton University Press.

Gutiérrez, G. and T. Philippon (2017). Investmentless Growth: An Empirical Investigation. Brookings Papers on Economic Activity 48(2 (Fall)), 89-190. 
Hadlock, C. J. and J. R. Pierce (2010, 03). New Evidence on Measuring Financial Constraints: Moving Beyond the KZ Index. The Review of Financial Studies 23(5), 19091940.

Hall, B. H. and J. Lerner (2010). Chapter 14 - the financing of r\&d and innovation. In B. H. Hall and N. Rosenberg (Eds.), Handbook of The Economics of Innovation, Vol. 1, Volume 1 of Handbook of the Economics of Innovation, pp. 609 - 639. North-Holland.

Haskel, J. and S. Westlake (2018). Capitalism without Capital: The Rise of the Intangible Economy. Princeton University Press.

Hottman, C. J., S. J. Redding, and D. E. Weinstein (2016, 03). Quantifying the Sources of Firm Heterogeneity *. The Quarterly Journal of Economics 131(3), 1291-1364.

Im, H., C. Mayer, and O. Sussman (2020, 01). Heterogeneity in investment spike financing.

Kremp, E. and P. Sevestre (2013). Did the crisis induce credit rationing for french smes? Journal of Banking and Finance $37(10), 3757$ - 3772.

Lemmon, M. L., M. R. Roberts, and J. F. Zender (2008). Back to the beginning: Persistence and the cross-section of corporate capital structure. The Journal of Finance 63(4), 15751608.

Levine, R. (2002). Bank-based or market-based financial systems: Which is better? Journal of Financial Intermediation 11(4), $398-428$.

Mian, A. and A. Sufi (2014). What Explains the 2007-2009 Drop in Employment? Econometrica 82(6), 2197-2223.

Morrow, P. M. and D. Trefler (2017, November). Endowments, Skill-Biased Technology, and Factor Prices: A Unified Approach to Trade. NBER Working Papers 24078, National Bureau of Economic Research, Inc.

Peters, R. H. and L. A. Taylor (2017). Intangible capital and the investment-q relation. Journal of Financial Economics 123(2), 251 - 272.

Petersen, M. A. (2008, 06). Estimating Standard Errors in Finance Panel Data Sets: Comparing Approaches. The Review of Financial Studies 22(1), 435-480.

Rajan, R. G. and L. Zingales (1995). What do we know about capital structure? some evidence from international data. The Journal of Finance 50(5), 1421-1460.

Rampini, A. A. and S. Viswanathan (2013). Collateral and capital structure. Journal of Financial Economics $109(2), 466$ - 492. 
Reenen, J. V. (2018, September). Increasing Differences Between Firms: Market Power and the Macro-Economy. CEP Discussion Papers dp1576, Centre for Economic Performance, LSE.

SMSG (2017). Access to public capital markets for SMEs. Technical report.

Whited, T. M. (2006). External finance constraints and the intertemporal pattern of intermittent investment. Journal of Financial Economics 81(3), 467 - 502. 


\section{Figures}

Figure 1: Balance sheet of an average firm (N.B. weights are based on firm sales)

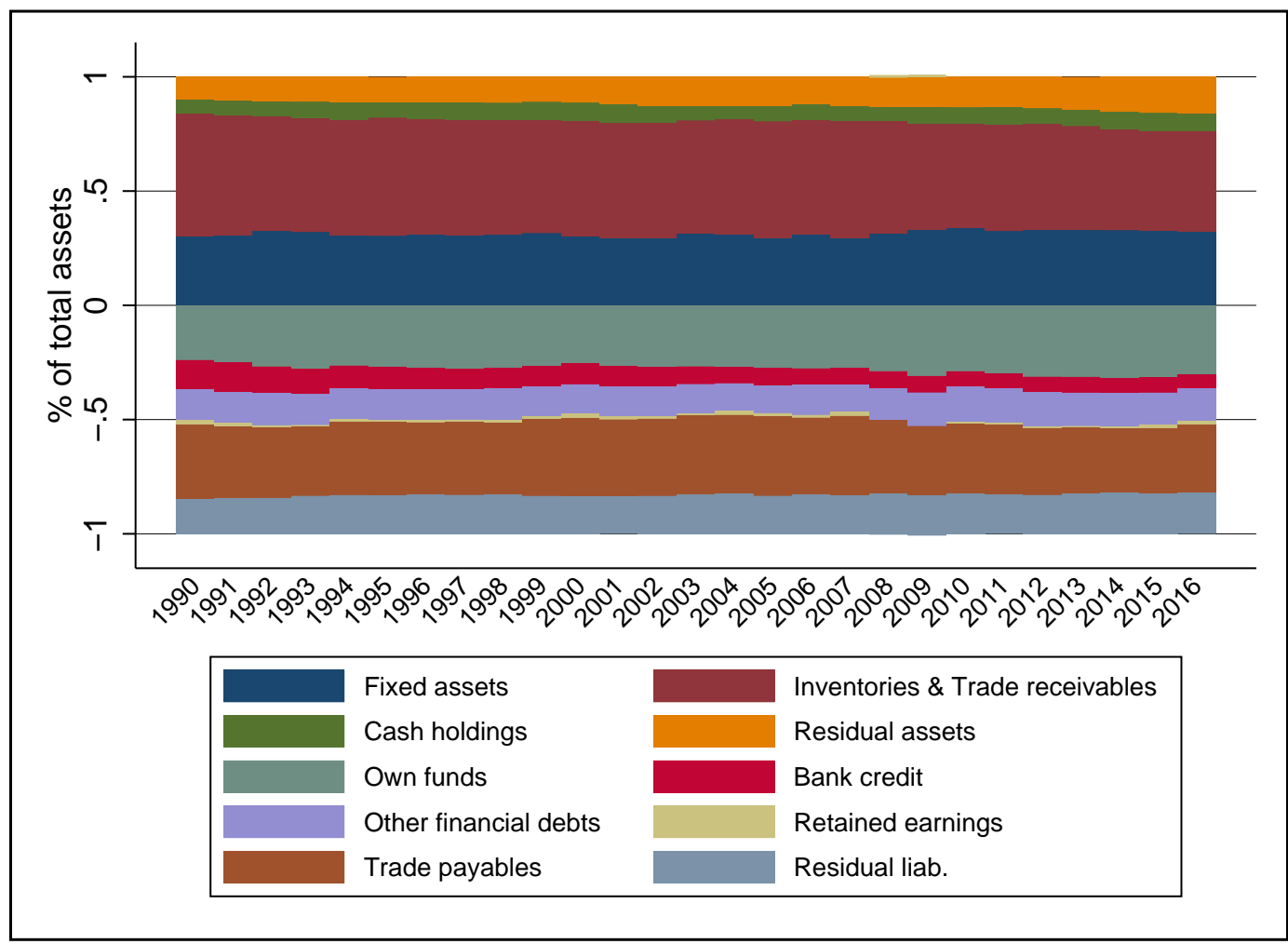

This figure shows the balance sheet composition of the weighed-average firm in France over the 1989-2016 period, weights are based on firm sales. Assets are reported with positive values, while liabilities are reported with negative values. All balance sheet components are deflated using the gross fixed capital formation price index as deflator. Firms operating in the real estate, financial and insurance sectors are excluded, as well as holding companies, self-employed entrepreneur and firms operating in the public or non-profit sector. We truncate observations where the change of any variables of interest belongs to the $99^{\text {th }}$ percentile (and the $1^{\text {st }}$ percentile for negative values). 
Figure 2: The relation between investment and bank credit

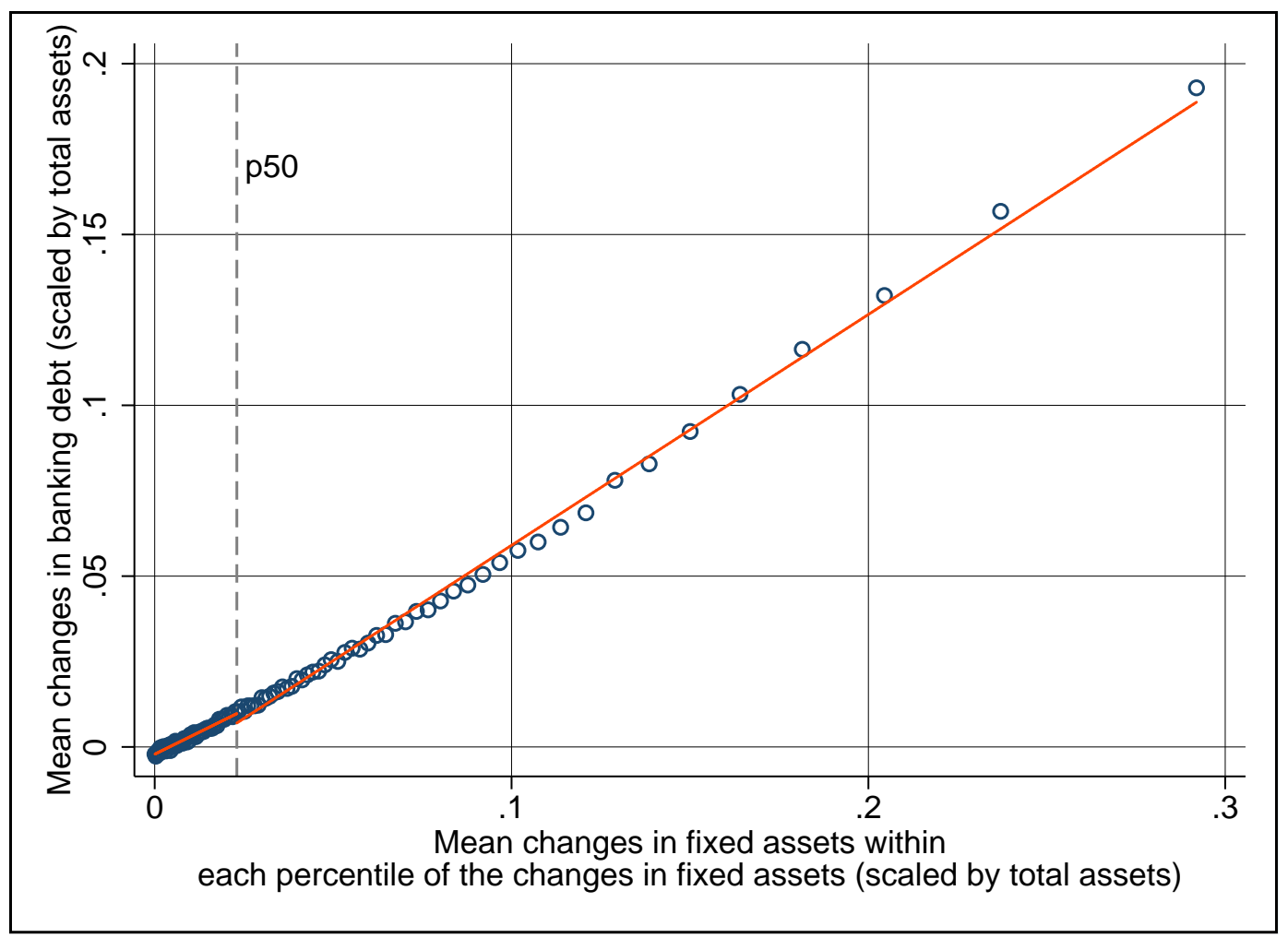

This figure shows the relation between change in bank credit and investment. More precisely for each percentile of investment this figure shows the average change in bank credit (y-axis) by average investment (x-axis) conditional on investing. Both variables are scaled by lagged and deflated total assets. Investment is defined as a strictly postive change in fixed assets. The same sample restrictions as in figure 1 are applied. Two fitted lines are plotted for the smallest investment (below the median investment) and the largest investment (above the median investment). 
Figure 3: Share of firms relying on bank credit while investing

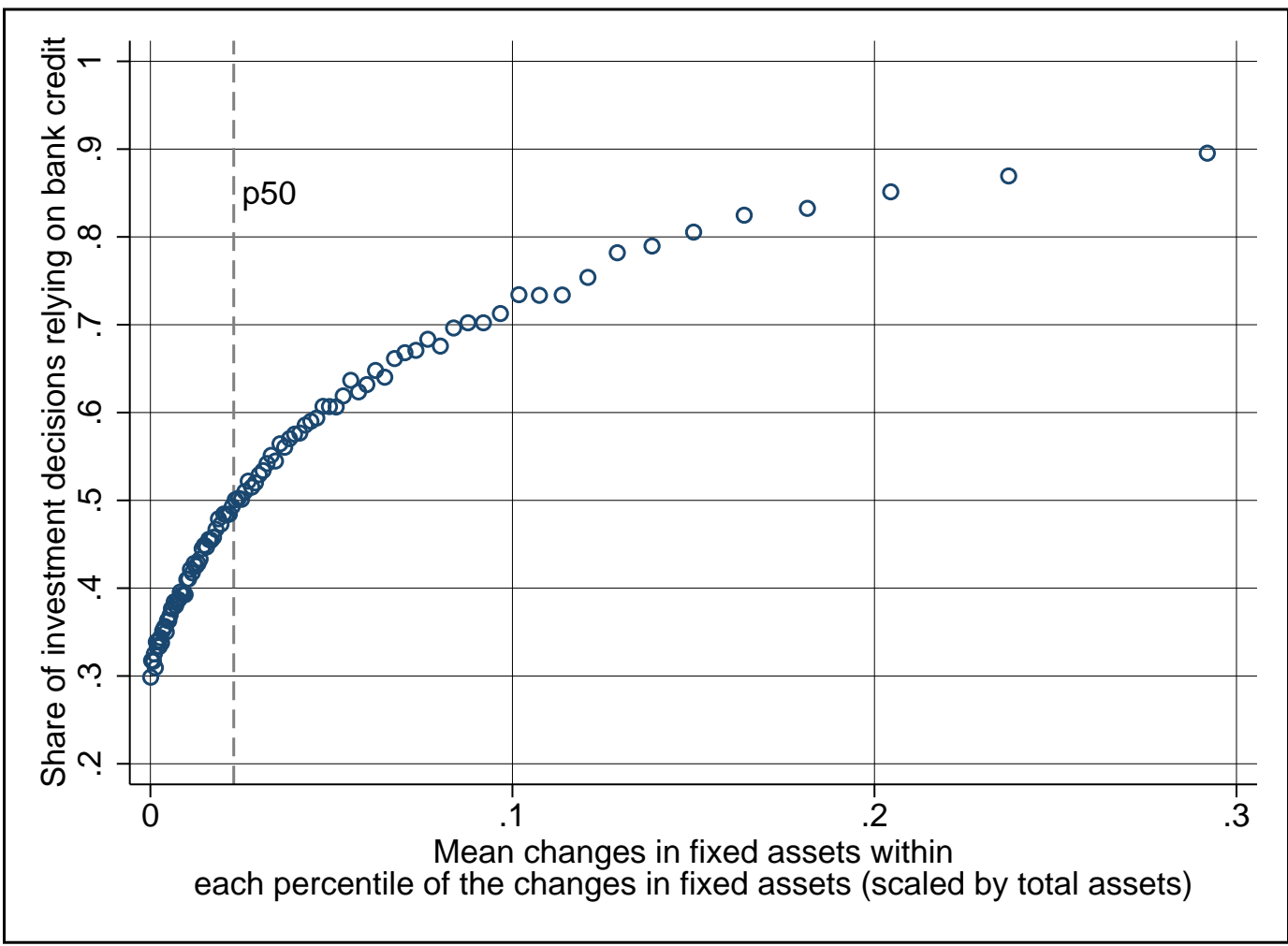

Within each percentile of the changes in fixed assets, this figure shows the share of firms relying on bank credit (y-axis) against the average change in fixed assets (x-axis), conditional on investing. Investment is defined as a strictly positive change in fixed assets and it is scaled by lagged and deflated total assets. The same sample restrictions as in figure 1 are applied. 
Figure 4: The relation between investment and bank credit: intensive margin

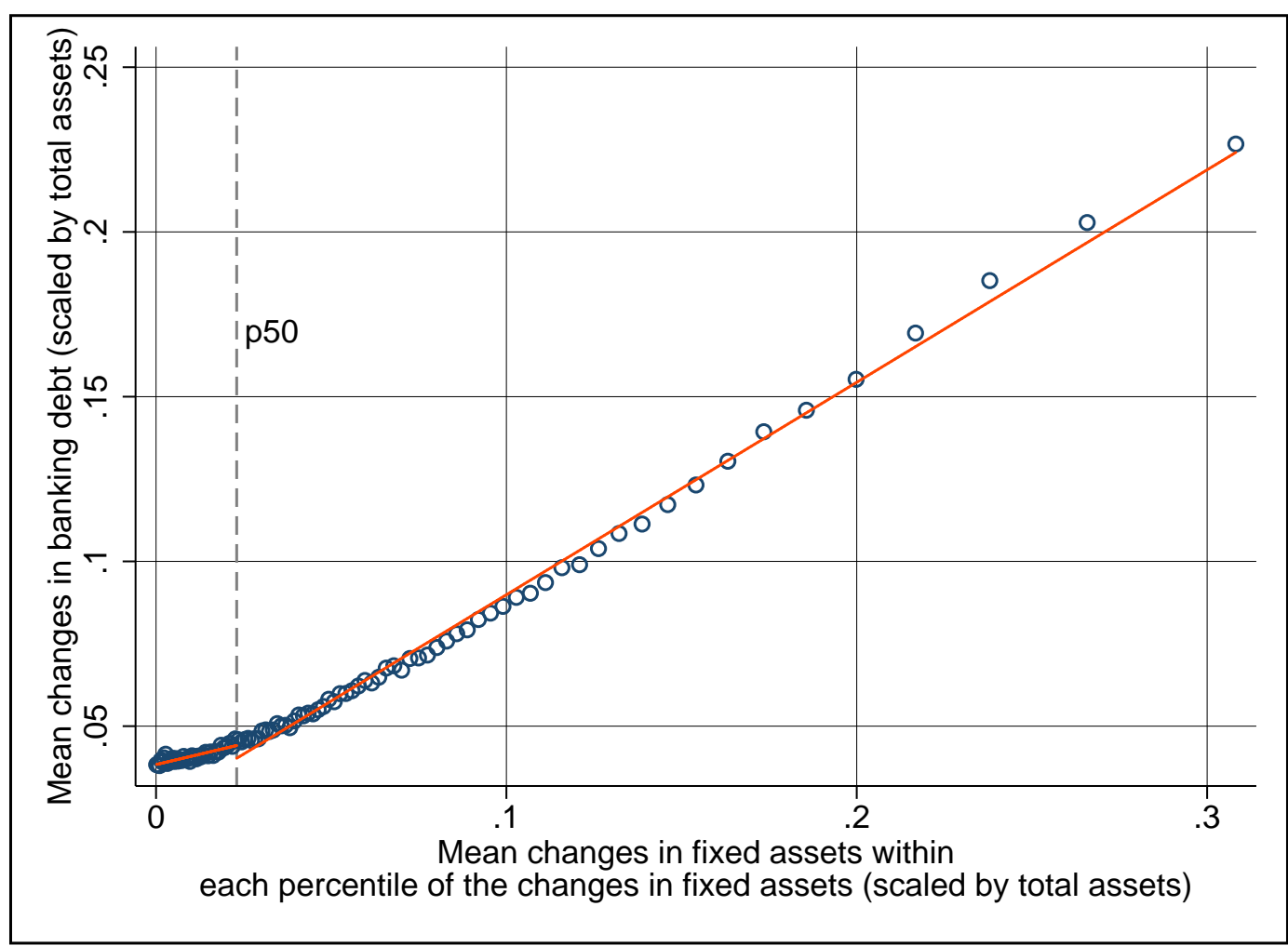

This figure shows the relation between changes in bank credit and changes in fixed assets at the intensive margin. Within each percentile of the changes in fixed assets, this figure shows the average change in bank credit (y-axis) against the average change in fixed assets conditional on both investing and borrowing from banks. Investment is defined as a strictly positive change in fixed assets. Both variables (the change in bank credit and the change in fixed assets) are scaled by lagged and deflated total assets. The same sample restrictions as in figure 1 are applied. Two fitted lines are plotted: the first one is fitted on the $50 \%$ smallest investments while the second one is fitted on the $50 \%$ largest investments. 
Figure 5: The funding of investment over the 1989-2016 period

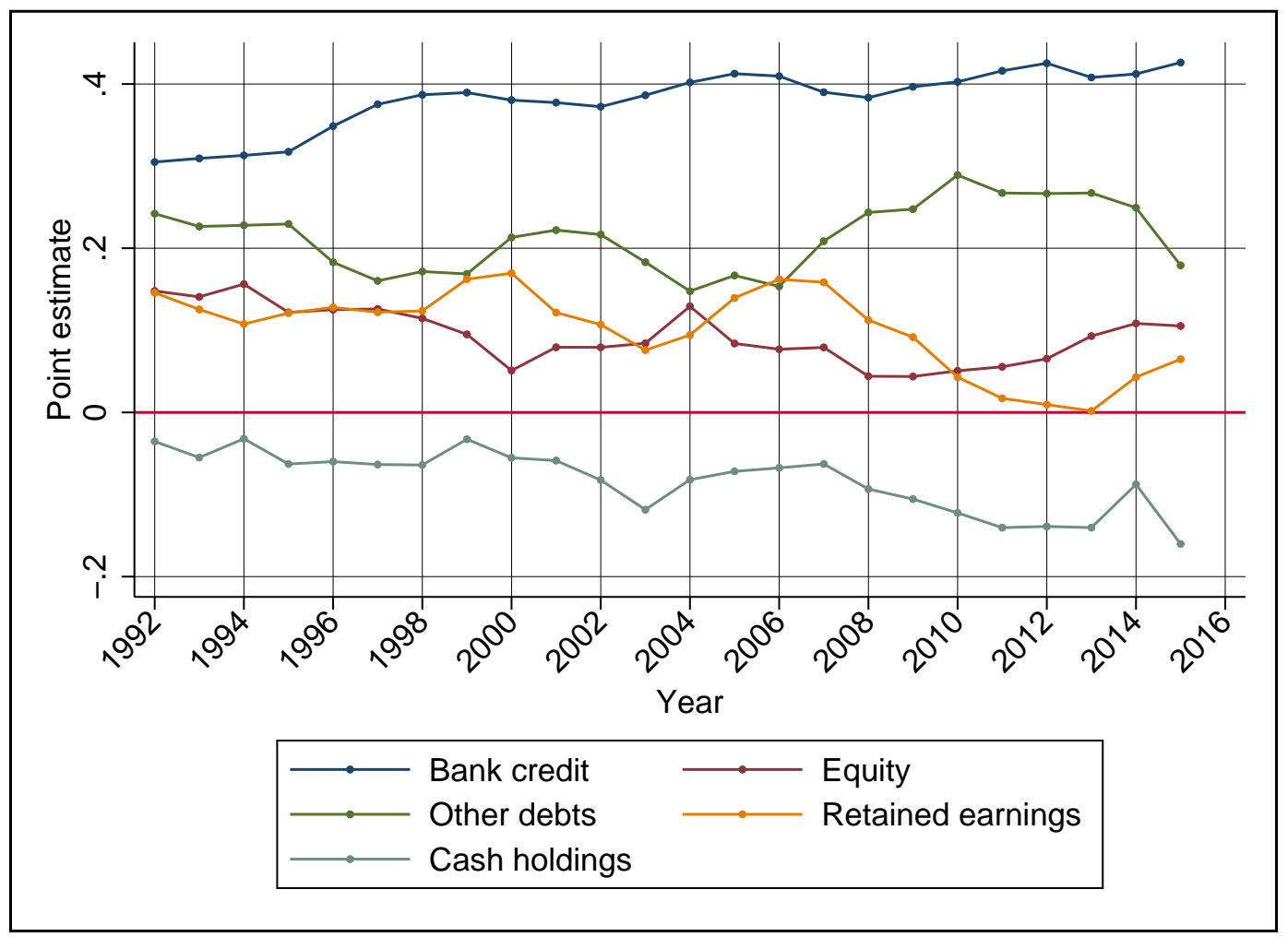

This figure shows the evolution of the estimated contribution of funding sources to the financing of fixed assets over the 1989-2016 period. The funding sources considered are bank credit, equity, retained earnings, other debts and cash holdings. Coefficients from specification 7 are estimated cross-sectionnally, i.e. within a given year, using a weighted-OLS estimator. The reported plots are the 4-year moving-average of these yearly contributions. The same sample restrictions as in figure 1 are applied. 


\section{Tables}

\subsection{Descriptive statistics}

Table 1: Summary statistics for selected balance sheet items (as a fraction of total assets)

\begin{tabular}{lcccccccc}
\hline \multicolumn{1}{c}{ Balance sheet items } & N & Mean & Std Dev. & p10 & p25 & Median & p75 & p90 \\
\hline \hline \multicolumn{3}{c}{ Asset Side } & & & & & \\
\hline Net Fixed Assets & $2,361,515$ & 0.24 & 0.19 & 0.04 & 0.09 & 0.18 & 0.33 & 0.52 \\
\hline of which: Net Tangible Fixed Assets & $2,361,515$ & 0.14 & 0.14 & 0.02 & 0.04 & 0.1 & 0.2 & 0.34 \\
\hline of which: Net InTangible Fixed Assets & $2,361,515$ & 0.06 & 0.13 & 0 & 0 & 0.01 & 0.06 & 0.2 \\
\hline Working capital assets & $2,361,515$ & 0.54 & 0.22 & 0.23 & 0.39 & 0.56 & 0.71 & 0.81 \\
\hline Cash holdings, net of dividends & $2,361,515$ & 0.14 & 0.16 & 0 & 0.01 & 0.09 & 0.22 & 0.37 \\
\hline Residual assets & $2,361,515$ & 0.09 & 0.09 & 0.02 & 0.03 & 0.06 & 0.1 & 0.19 \\
\hline & \multicolumn{2}{c}{ Liability Side } & & & & & & \\
\hline Bank Credit & $2,361,515$ & 0.12 & 0 & 0.01 & 0.07 & 0.17 & 0.29 & 0.1 \\
\hline of which: ST bank credit & $2,346,937$ & 0.03 & 0.06 & 0 & 0 & 0 & 0.02 & 0.1 \\
\hline of which: LT bank credit & $2,360,378$ & 0.08 & 0.1 & 0 & 0 & 0.04 & 0.12 & 0.22 \\
\hline Other financial debts & $2,361,515$ & 0.08 & 0.1 & 0 & 0.01 & 0.04 & 0.11 & 0.22 \\
\hline Equity, net of retained earnings & $2,361,515$ & 0.34 & 0.19 & 0.11 & 0.19 & 0.31 & 0.47 & 0.61 \\
\hline Retained earnings, net of dividends & $2,361,515$ & 0.02 & 0.06 & -0.04 & 0 & 0.02 & 0.06 & 0.1 \\
\hline Trade payables & $2,361,515$ & 0.29 & 0.17 & 0.09 & 0.16 & 0.26 & 0.4 & 0.53 \\
\hline Residual liabilities & $2,361,515$ & 0.17 & 0.11 & 0.06 & 0.09 & 0.14 & 0.22 & 0.31 \\
\hline \hline
\end{tabular}

This table presents the summary statistics of the main balance sheet items of French firms over the 1989-2016 period. All variables are deflated using the gross fixed capital formation price index as deflator. All observations where the change of any variables of interst belongs to the $99^{t h}$ percentile (and the $1^{\text {st }}$ percentile for negative values) are truncated. We exclude all firms operating in the real estate, financial and insurance sectors as well as holding companies, self-employed entrepreneur and firms operating in the public or non-profit sector. 
Table 2: Descriptive statistics for selected corporate variables

\begin{tabular}{lcccccccc}
\hline \hline \multicolumn{1}{c}{ Balance sheet items } & $\mathbf{N}$ & Mean & Std Dev. & p10 & p25 & Median & p75 & p90 \\
\hline \hline Total assets (millions of euros) & $2,361,515$ & 10.59 & 475.22 & 0.48 & 0.74 & 1.38 & 3.29 & 9.1 \\
\hline Total sales (millions of euros) & $2,361,515$ & 14.79 & 262.82 & 1.06 & 1.47 & 2.66 & 6.39 & 17.47 \\
\hline Employment & $2,361,515$ & 59.6 & 888.14 & 5 & 9 & 17 & 36 & 81 \\
\hline \hline
\end{tabular}

This table presents the descriptive statistics of selected corporate variables of French firms over the 1989-2016 period.

Selected variables are the total assets, the total sales and the employment. Total assets and total sales are deflated using the gross fixed capital formation price index as deflator. The same restrictions as in table 1 are applied. 
Table 3: Descriptive statistics decomposed by size classes

\begin{tabular}{|c|c|c|c|c|c|c|}
\hline & \multicolumn{6}{|c|}{ Size class } \\
\hline & Bottom $25 \%$ & )p25-p50] & )p50-p75] & )p75-p90] & )p90-p95] & Top 5\% \\
\hline \multicolumn{7}{|c|}{ Minimum value: threshold of entry in the size class based on total sales } \\
\hline 1990 & 0.75 & 1.72 & 3.15 & 7.25 & 17.63 & 33.38 \\
\hline 2000 & 0.75 & 1.49 & 2.68 & 6.38 & 16.69 & 32.13 \\
\hline 2010 & 0.75 & 1.42 & 2.54 & 6.17 & 17.7 & 35.15 \\
\hline 2015 & 0.75 & 1.5 & 2.77 & 6.98 & 20.39 & 41 \\
\hline \multicolumn{7}{|c|}{ Mean value: average sales within each size class } \\
\hline 1990 & 1.27 & 2.35 & 4.77 & 11.02 & 23.81 & 188.55 \\
\hline 2000 & 1.14 & 2 & 4.11 & 10.1 & 22.67 & 195.38 \\
\hline 2010 & 1.1 & 1.9 & 3.91 & 10.24 & 24.58 & 228.67 \\
\hline 2015 & 1.14 & 2.05 & 4.35 & 11.75 & 28.5 & 237.49 \\
\hline \multicolumn{7}{|c|}{ Median value: median sales average sales within each size class } \\
\hline 1990 & 1.26 & 2.3 & 4.55 & 10.39 & 22.95 & 69 \\
\hline 2000 & 1.14 & 1.96 & 3.91 & 9.41 & 21.81 & 60.99 \\
\hline 2010 & 1.1 & 1.87 & 3.7 & 9.44 & 23.8 & 67.18 \\
\hline 2015 & 1.13 & 2 & 4.11 & 10.84 & 27.51 & 77.7 \\
\hline
\end{tabular}

This table presents the minimum value, the average value and the median value of total sales of French firms over the 1989-2016 period, broken down by size class. Size classes are built using the distribution of total sales. All variables are deflated using the gross fixed capital formation price index as deflator. The same restrictions as in table 1 are applied. 
Table 4: Cumulative distribution for selected corporate variables in 2016 broken down by size class

\begin{tabular}{lcccccc}
\hline \hline & \multicolumn{7}{c}{ Size class } \\
\cline { 2 - 7 } & Bottom 25\% & )p25-p50] & )p50-p75] & )p75-p90] & )p90-p95] & Top 5\% \\
\hline \hline Investment & 0.01 & 0.02 & 0.04 & 0.07 & 0.06 & 0.80 \\
\hline Total Sales & 0.02 & 0.03 & 0.06 & 0.10 & 0.08 & 0.71 \\
\hline Bank Credit & 0.02 & 0.04 & 0.08 & 0.14 & 0.10 & 0.61 \\
\hline Employment & 0.04 & 0.06 & 0.10 & 0.13 & 0.09 & 0.59 \\
\hline Fixed Assets & 0.01 & 0.02 & 0.03 & 0.04 & 0.04 & 0.86 \\
\hline Total Assets & 0.01 & 0.02 & 0.05 & 0.08 & 0.06 & 0.78 \\
\hline \hline
\end{tabular}

This table presents the cumulative distribution of some corporate variables of French firms over the 1989-2016 period, broken down by size class: namely firm's investment, sales, bank credit, employment, fixed assets and total assets. Size classes are built using the distribution of total sales. All variables are deflated using the gross fixed capital formation price index as deflator. The same restrictions as in table 1 are applied. 
Table 5: Median value of balance sheet items within each size class (as a fraction of total assets)

\begin{tabular}{|c|c|c|c|c|c|c|}
\hline Balance sheet items & Bottom 25\% & ) $\mathrm{p} 25-\mathrm{p} 50]$ & ) $\mathrm{p} 50-\mathrm{p} 75]$ & ) p75-p90] & ) p90-p95] & Top 5\% \\
\hline \multicolumn{7}{|c|}{ Asset Side } \\
\hline Net Fixed Assets & 0.21 & 0.18 & 0.17 & 0.17 & 0.19 & 0.24 \\
\hline of which Net Tangible Fixed Assets & 0.10 & 0.10 & 0.10 & 0.10 & 0.11 & 0.12 \\
\hline of which Net InTangible Fixed Assets & 0.01 & 0.01 & 0.01 & 0.00 & 0.01 & 0.01 \\
\hline Working capital assets & 0.52 & 0.56 & 0.59 & 0.60 & 0.60 & 0.53 \\
\hline Cash holdings, net of dividends & 0.11 & 0.10 & 0.09 & 0.07 & 0.04 & 0.02 \\
\hline Residual assets & 0.05 & 0.05 & 0.06 & 0.07 & 0.08 & 0.09 \\
\hline \multicolumn{7}{|c|}{ Liability Side } \\
\hline Bank Credit & 0.07 & 0.07 & 0.06 & 0.07 & 0.07 & 0.04 \\
\hline of which ST bank credit & 0.00 & 0.00 & 0.00 & 0.00 & 0.00 & 0.00 \\
\hline of which LT bank credit & 0.05 & 0.04 & 0.04 & 0.03 & 0.03 & 0.01 \\
\hline Other financial debts & 0.04 & 0.04 & 0.03 & 0.04 & 0.05 & 0.07 \\
\hline Equity, net of retained earnings & 0.35 & 0.32 & 0.31 & 0.29 & 0.27 & 0.28 \\
\hline Retained earnings, net of dividends & 0.02 & 0.03 & 0.02 & 0.02 & 0.02 & 0.01 \\
\hline Trade payables & 0.22 & 0.25 & 0.29 & 0.32 & 0.32 & 0.30 \\
\hline Residual liabilities & 0.15 & 0.15 & 0.14 & 0.12 & 0.11 & 0.12 \\
\hline
\end{tabular}

This table presents the median value of the main balance sheet items (expressed as a fraction of total assets) of French firms over the 1989-2016 period within each size class. Size classes are built using the distribution of total sales. All variables are deflated using the gross fixed capital formation price index as deflator. The same restrictions as in table 1 apply. 
Table 6: Frequency and intensity of investment decisions by size classes

\begin{tabular}{lccccccccc}
\hline \hline Balance sheet items & $\mathbf{N}$ & Mean & Std Dev. & p10 & p25 & p50 & p75 & p90 \\
\hline \hline Frequency of & investment decision & (years per & investment & decision) & & \\
\hline Bottom 25\% & 569,286 & 3.55 & 2.20 & 1.83 & 2.25 & 2.89 & 4.00 & 6.00 \\
\hline )p25-p50] & 577,650 & 3.29 & 2.07 & 1.75 & 2.13 & 2.67 & 3.67 & 5.33 \\
\hline )p50-p75] & 582,977 & 3.00 & 1.80 & 1.69 & 2.00 & 2.50 & 3.33 & 4.67 \\
\hline )p75-p90] & 351,185 & 2.87 & 1.76 & 1.62 & 1.92 & 2.40 & 3.17 & 4.50 \\
\hline )p90-p95] & 117,381 & 2.74 & 1.62 & 1.56 & 1.86 & 2.33 & 3.00 & 4.20 \\
\hline Top 5\% & 117,343 & 2.56 & 1.61 & 1.44 & 1.71 & 2.13 & 2.83 & 3.83 \\
\hline Investment rates & $($ Positive changes in net & Fixed Assets over & total & assets, & deflated) \\
\hline Bottom 25\% & 152,750 & 0.41 & 1.28 & 0.02 & 0.05 & 0.16 & 0.4 & 0.88 \\
\hline )p25-p50] & 181,844 & 0.41 & 1.63 & 0.02 & 0.06 & 0.17 & 0.41 & 0.87 \\
\hline )p50-p75] & 199,634 & 0.39 & 1.82 & 0.02 & 0.06 & 0.16 & 0.39 & 0.82 \\
\hline )p75-p90] & 125,717 & 0.34 & 1.75 & 0.02 & 0.05 & 0.14 & 0.34 & 0.7 \\
\hline )p90-p95] & 43,957 & 0.29 & 1.72 & 0.02 & 0.05 & 0.12 & 0.29 & 0.59 \\
\hline Top 5\% & 46,655 & 0.23 & 1.68 & 0.01 & 0.04 & 0.1 & 0.22 & 0.46 \\
\hline \hline
\end{tabular}

This table presents the frequency and the intensity of investment decisions made by French firms over the 1989-2016 period. Investment is computed as the positive variation in net Fixed Assets. The frequency of investment expresses the average number of years surrounding two investments decisions. It is defined as the inverse of the average number of investment decision undertaken by years for a given firm. The intensity of investment is defined as ratio of investment over fixed assets for a given firm. All variables are deflated using the gross fixed capital formation price index as deflator. The same restrictions as in table 1 are applied. 


\subsection{Regression results}

Table 7: The funding of investment and working capital: unweighted estimation

\begin{tabular}{|c|c|c|c|c|c|c|}
\hline & $\Delta$ Bank Credit & $\Delta$ Other Debts & $\Delta$ Equity (net of RE) & Retained Earnings & $\Delta$ Cash Holdings & $\Delta$ Residual Liab. \\
\hline$\Delta$ Fixed Assets & $\begin{array}{c}0.577^{* * *} \\
(0.002)\end{array}$ & $\begin{array}{c}0.099 * * * \\
(0.001)\end{array}$ & $\begin{array}{c}0.009^{* * *} \\
(0.001)\end{array}$ & $\begin{array}{c}0.105^{* * *} \\
(0.001)\end{array}$ & $\begin{array}{c}-0.101^{* * *} \\
(0.002)\end{array}$ & $\begin{array}{c}0.109^{* * *} \\
(0.001)\end{array}$ \\
\hline$\Delta$ net WCA & $\begin{array}{c}0.188^{* * *} \\
(0.001)\end{array}$ & $\begin{array}{c}0.134^{* * *} \\
(0.001)\end{array}$ & $\begin{array}{c}0.008^{* * *} \\
(0.000)\end{array}$ & $\begin{array}{c}0.156^{* * *} \\
(0.001)\end{array}$ & $\begin{array}{c}-0.335^{* * *} \\
(0.002)\end{array}$ & $\begin{array}{c}0.178^{* * *} \\
(0.001)\end{array}$ \\
\hline$\Delta$ Residual Assets & $\begin{array}{c}0.225^{* * * *} \\
(0.001)\end{array}$ & $\begin{array}{c}0.148^{* * *} \\
(0.002)\end{array}$ & $\begin{array}{c}0.007^{* * *} \\
(0.001)\end{array}$ & $\begin{array}{c}0.117^{* * *} \\
(0.001)\end{array}$ & $\begin{array}{c}-0.370^{* * *} \\
(0.002)\end{array}$ & $\begin{array}{c}0.132^{* * *} \\
(0.001)\end{array}$ \\
\hline Observations & 907,843 & 907,843 & 907,843 & 907,843 & 907,843 & 907,843 \\
\hline Adj. R-squared & 0.455 & 0.124 & 0.589 & 0.285 & 0.502 & 0.174 \\
\hline Control variables & Yes & Yes & Yes & Yes & Yes & Yes \\
\hline Weights & No & $\mathrm{No}$ & No & $\mathrm{No}$ & No & No \\
\hline Cluster & Firm level & Firm level & Firm level & Firm level & Firm level & Firm level \\
\hline
\end{tabular}

This tables reports the contribution of various funding sources (namely bank credit, equity, retained earnings, cash holdings, others debts and residual liabilities) to the financing of fixed assets, working capital assets and residual assets. The dependent variables are the changes in bank credit (column (1)), the changes in other debt (column (2)), the changes in equity (column (3)), the changes in retained earnings (column (4)), the changes in cash holdings (column (5)) and the changes in residual liabilities (column (6)). The explanatory variables are the changes in fixed assets ( $\Delta$ Fixed Assets), the changes in net working capital assets $(\Delta$ net WCA) and the changes in residual assets ( $\Delta$ Residual Assets). The following control variables are included in all specification: the share of equity over total assets, the share of cash holdings over total assets, the share of bank credit over total assets, the growth rate of sales, the ratio of dividends to sales and finally the log of total assets. All observations where the change of any variables of interest belongs to the $99^{\text {th }}$ percentile (and the $1^{\text {st }}$ percentile in case of negative values) are truncated. All firms operating in the real estate, financial and insurance sectors are excluded, as well as holding companies, self-employed entrepreneur and firms operating in the public or non-profit sector. All variables are deflated using the gross fixed capital formation price index as deflator. All variables are centered at firm level. Standard errors, reported in parentheses, are clustered at firm level. ***, **, * indicate significance levels at $1 \%, 5 \%$ and $10 \%$. 
Table 8: The funding of investment and working capital: weighted estimation

\begin{tabular}{|c|c|c|c|c|c|c|}
\hline & $\Delta$ Bank Credit & $\Delta$ Other Debts & $\Delta$ Equity (net of RE) & Retained Earnings & $\Delta$ Cash Holdings & $\Delta$ Residual Liab \\
\hline$\Delta$ Fixed Assets & $\begin{array}{c}0.377^{* * *} * \\
(0.017)\end{array}$ & $\begin{array}{c}0.219^{* * *} \\
(0.018)\end{array}$ & $\begin{array}{c}0.084^{* * *} \\
(0.016)\end{array}$ & $\begin{array}{c}0.110^{* * * *} \\
(0.011)\end{array}$ & $\begin{array}{c}-0.092^{* * *} \\
(0.017)\end{array}$ & $\begin{array}{c}0.116^{* * *} \\
(0.008)\end{array}$ \\
\hline$\Delta$ net WCA & $\begin{array}{c}0.191^{* * *} \\
(0.010)\end{array}$ & $\begin{array}{c}0.264^{* * *} \\
(0.011)\end{array}$ & $\begin{array}{c}0.040^{* * *} \\
(0.010)\end{array}$ & $\begin{array}{c}0.138^{* * *} * \\
(0.011)\end{array}$ & $\begin{array}{c}-0.226^{* * *} \\
(0.012)\end{array}$ & $\begin{array}{c}0.140 * * * \\
(0.006)\end{array}$ \\
\hline$\Delta$ Residual Assets & $\begin{array}{c}0.188^{* * *} \\
(0.013)\end{array}$ & $\begin{array}{c}0.278^{* * *} \\
(0.013)\end{array}$ & $\begin{array}{c}0.041^{* * * *} \\
(0.007)\end{array}$ & $\begin{array}{c}0.149^{* * *} \\
(0.009)\end{array}$ & $\begin{array}{c}-0.201^{* * *} \\
(0.014)\end{array}$ & $\begin{array}{c}0.142^{* * *} \\
(0.009)\end{array}$ \\
\hline Observations & 907,843 & 907,843 & 907,843 & 907,843 & 907,843 & 907,843 \\
\hline Adj. R-squared & 0.354 & 0.222 & 0.398 & 0.302 & 0.418 & 0.148 \\
\hline Control variables & Yes & Yes & Yes & Yes & Yes & Yes \\
\hline Weights & Yes & Yes & Yes & Yes & Yes & Yes \\
\hline Cluster & Firm level & Firm level & Firm level & Firm level & Firm level & Firm level \\
\hline
\end{tabular}

The coefficients in this table are estimated from the same specifications with the same restrictions as in table 7 using a weighted-OLS estimator, weighted by firm's sales. Standard errors, reported in parentheses, are clustered at firm level. ***, **, * indicate significance levels at $1 \%, 5 \%$ and $10 \%$. 
Table 9: The funding of investment and working capital by firm size: unweighted estimation

\begin{tabular}{|c|c|c|c|c|c|c|}
\hline & & $\Delta$ Bank Credit & $\Delta$ Other Debts & $\Delta$ Equity (net of RE) & Retained Earnings & $\Delta$ Cash Holdings \\
\hline \multirow{6}{*}{$\Delta$ Fixed Assets $\times$} & Bottom 25\% & $\begin{array}{c}0.630^{* * *} \\
(0.003)\end{array}$ & $\begin{array}{c}0.081^{* * *} \\
(0.002)\end{array}$ & $\begin{array}{l}-0.000 \\
(0.001)\end{array}$ & $\begin{array}{c}0.092^{* * *} \\
(0.002)\end{array}$ & $\begin{array}{c}-0.121^{* * *} \\
(0.003)\end{array}$ \\
\hline & p25-p50] & $\begin{array}{c}0.603^{* * *} \\
(0.003)\end{array}$ & $\begin{array}{c}0.080^{* * *} \\
(0.002)\end{array}$ & $\begin{array}{c}0.002 \\
(0.001)\end{array}$ & $\begin{array}{c}0.099 * * * \\
(0.002)\end{array}$ & $\begin{array}{c}-0.128^{* * *} \\
(0.003)\end{array}$ \\
\hline & )p50-p75] & $\begin{array}{c}0.571^{* * *} \\
(0.003)\end{array}$ & $\begin{array}{c}0.099 * * * \\
(0.002)\end{array}$ & $\begin{array}{c}0.008^{* * *} \\
(0.001)\end{array}$ & $\begin{array}{c}0.093^{* * *} \\
(0.002)\end{array}$ & $\begin{array}{c}-0.132^{* * *} \\
(0.003)\end{array}$ \\
\hline & )p75-p90] & $\begin{array}{c}0.540^{* * *} \\
(0.004)\end{array}$ & $\begin{array}{c}0.131^{* * *} \\
(0.004)\end{array}$ & $\begin{array}{c}0.020^{* * *} \\
(0.002)\end{array}$ & $\begin{array}{c}0.077^{* * *} \\
(0.003)\end{array}$ & $\begin{array}{c}-0.122^{* * *} \\
(0.004)\end{array}$ \\
\hline & )p90-p95] & $\begin{array}{c}0.495^{* * *} \\
(0.007)\end{array}$ & $\begin{array}{c}0.158^{* * *} \\
(0.007)\end{array}$ & $\begin{array}{c}0.039 * * * \\
(0.004)\end{array}$ & $\begin{array}{c}0.078^{* * *} \\
(0.005)\end{array}$ & $\begin{array}{c}-0.105^{* * *} \\
(0.007)\end{array}$ \\
\hline & Top 5\% & $\begin{array}{c}0.391^{* * *} \\
(0.008)\end{array}$ & $\begin{array}{c}0.231^{* * *} \\
(0.008)\end{array}$ & $\begin{array}{c}0.076^{* * *} \\
(0.004)\end{array}$ & $\begin{array}{c}0.076^{* * *} \\
(0.005)\end{array}$ & $\begin{array}{c}-0.097^{* * *} \\
(0.006)\end{array}$ \\
\hline \multirow{6}{*}{$\Delta$ net WCA $\times$} & Bottom 25\% & $\begin{array}{c}0.182^{* * *} \\
(0.002)\end{array}$ & $\begin{array}{c}0.111^{* * *} \\
(0.001)\end{array}$ & $\begin{array}{c}0.008^{* * *} * \\
(0.001)\end{array}$ & $\begin{array}{c}0.145^{* * *} \\
(0.001)\end{array}$ & $\begin{array}{c}-0.393^{* * *} \\
(0.002)\end{array}$ \\
\hline & )p25-p50] & $\begin{array}{c}0.185^{* * *} \\
(0.001)\end{array}$ & $\begin{array}{c}0.112^{* * *} \\
(0.001)\end{array}$ & $\begin{array}{c}0.008^{* * *} \\
(0.001)\end{array}$ & $\begin{array}{c}0.139^{* * *} \\
(0.001)\end{array}$ & $\begin{array}{c}-0.386^{* * *} \\
(0.002)\end{array}$ \\
\hline & )p50-p75] & $\begin{array}{c}0.192^{* * *} \\
(0.001)\end{array}$ & $\begin{array}{c}0.130^{* * *} \\
(0.001)\end{array}$ & $\begin{array}{c}0.009^{* * *} \\
(0.001)\end{array}$ & $\begin{array}{c}0.136^{* * *} \\
(0.001)\end{array}$ & $\begin{array}{c}-0.372^{* * *} \\
(0.002)\end{array}$ \\
\hline & )p75-p90] & $\begin{array}{c}0.213^{* * *} \\
(0.002)\end{array}$ & $\begin{array}{c}0.171^{* * *} \\
(0.002)\end{array}$ & $\begin{array}{c}0.014^{* * *} \\
(0.001)\end{array}$ & $\begin{array}{c}0.126^{* * *} \\
(0.002)\end{array}$ & $\begin{array}{c}-0.333^{* * *} \\
(0.003)\end{array}$ \\
\hline & )p90-p95] & $0.235^{* * *}$ & $0.222^{* * *}$ & $0.018^{* * *}$ & $0.122^{* * *}$ & $-0.271^{* * *}$ \\
\hline & Top 5\% & $\begin{array}{c}0.231^{* * *} \\
(0.004)\end{array}$ & $\begin{array}{c}0.287^{* * *} \\
(0.005)\end{array}$ & $\begin{array}{c}0.026^{* * *} \\
(0.002)\end{array}$ & $\begin{array}{c}0.117^{* * *} \\
(0.003)\end{array}$ & $\begin{array}{c}-0.212^{* * *} \\
(0.004)\end{array}$ \\
\hline Observations & & 907,843 & 907,843 & 907,843 & 907,843 & 907,843 \\
\hline Adj. R-squared & & 0.460 & 0.135 & 0.592 & 0.331 & 0.536 \\
\hline Control variables & & Yes & Yes & Yes & Yes & Yes \\
\hline Weights & & No & No & No & No & No \\
\hline Cluster & & Firm level & Firm level & Firm level & Firm level & Firm level \\
\hline
\end{tabular}

This tables reports the contribution of several funding sources to the financing of asset components. The analysis is broken down by firm size class. The dependent variables are the changes in bank credit (column (1)), the changes in other debt (column (2)), the changes in equity (column (3)), the changes in retained earnings (column (4)), the changes in cash holdings (column (5)) and the changes in residual liabilities (column (6)). The explanatory variables are the changes in fixed assets ( $\Delta$ Fixed Assets), the changes in net working capital assets $(\Delta$ net WCA $)$ and the changes in residual assets ( $\Delta$ Residual Assets). The firm size classes are defined based on quantiles of the yearly distribution of firm sales. The same control variables are included in the regressions as in table 7. All variables are deflated using the gross fixed capital formation price index as deflator. All variables are centered at firm level. The same restrictions are imposed as in table 7. Standard errors, reported in parentheses, are clustered at firm level. ${ }^{* * *}, * *, *$ indicate significance levels at $1 \%, 5 \%$ and $10 \%$. 
Table 10: The funding of investment and working capital by firm size: weighted estimation

\begin{tabular}{|c|c|c|c|c|c|c|}
\hline & & $\Delta$ Bank Credit & $\Delta$ Other Debts & $\Delta$ Equity (net of RE) & Retained Earnings & $\Delta$ Cash Holdings \\
\hline \multirow{12}{*}{$\Delta$ Fixed Assets $\times$} & \multirow[t]{2}{*}{ Bottom 25\% } & $0.628^{* * *}$ & $0.081^{* * *}$ & -0.000 & $0.092^{* * *}$ & $-0.121 * * *$ \\
\hline & & $(0.003)$ & $(0.002)$ & $(0.001)$ & $(0.002)$ & $(0.003)$ \\
\hline & \multirow[t]{2}{*}{ )p25-p50] } & $0.600^{* * *}$ & $0.081^{* * *}$ & $0.002^{*}$ & $0.100^{* * *}$ & $-0.127 * * *$ \\
\hline & & $(0.003)$ & $(0.002)$ & $(0.001)$ & $(0.002)$ & $(0.003)$ \\
\hline & \multirow[t]{2}{*}{ p50-p75] } & $0.568^{* * *}$ & $0.100^{* * *}$ & $0.009^{* * *}$ & $0.094^{* * *}$ & $-0.131^{* * *}$ \\
\hline & & $(0.003)$ & $(0.003)$ & $(0.001)$ & $(0.002)$ & $(0.003)$ \\
\hline & \multirow[t]{2}{*}{ )p75-p90] } & $0.541^{* * *}$ & $0.134^{* * *}$ & 0.020 *** & $0.076^{* * *}$ & $-0.119 * * *$ \\
\hline & & $(0.004)$ & $(0.004)$ & $(0.002)$ & $(0.003)$ & $(0.004)$ \\
\hline & \multirow{2}{*}{ )p90-p95] } & $0.497^{* * *}$ & $0.161^{* * *}$ & $0.041^{* * *}$ & $0.077^{* * *}$ & $-0.101^{* * *}$ \\
\hline & & $(0.008)$ & $(0.007)$ & $(0.004)$ & $(0.005)$ & $(0.007)$ \\
\hline & \multirow[t]{2}{*}{ Top 5\% } & $0.248^{* * *}$ & $0.288^{* * *}$ & $0.128 * * *$ & $0.122^{* * *}$ & $-0.094^{* * *}$ \\
\hline & & $(0.024)$ & $(0.029)$ & $(0.024)$ & $(0.020)$ & $(0.030)$ \\
\hline \multirow{12}{*}{$\Delta$ net $\mathrm{WCA} \times$} & \multirow[t]{2}{*}{ Bottom 25\% } & $0.182^{* * *}$ & $0.110^{* * *}$ & $0.008^{* * *}$ & $0.145^{* * *}$ & $-0.392^{* * *}$ \\
\hline & & $(0.002)$ & $(0.001)$ & $(0.001)$ & $(0.001)$ & $(0.002)$ \\
\hline & \multirow[t]{2}{*}{ p25-p50] } & $0.186^{* * *}$ & $0.112^{* * *}$ & $0.008^{* * *}$ & $0.138^{* * *}$ & $-0.385^{* * *}$ \\
\hline & & $(0.001)$ & $(0.001)$ & $(0.001)$ & $(0.001)$ & $(0.002)$ \\
\hline & \multirow{2}{*}{ )p50-p75] } & $0.193^{* * *}$ & $0.132^{* * *}$ & $0.009 * * *$ & $0.135^{* * *}$ & $-0.369 * * *$ \\
\hline & & $(0.002)$ & $(0.002)$ & $(0.001)$ & $(0.001)$ & $(0.002)$ \\
\hline & \multirow[t]{2}{*}{ )p75-p90] } & $0.215^{* * *}$ & $0.176^{* * *}$ & $0.014^{* * *}$ & $0.125^{* * *}$ & $-0.329 * * *$ \\
\hline & & $(0.002)$ & $(0.002)$ & $(0.001)$ & $(0.002)$ & $(0.003)$ \\
\hline & \multirow[t]{2}{*}{ )p90-p95] } & $0.233^{* * *}$ & $0.227^{* * *}$ & $0.018^{* * *}$ & $0.122^{* * *}$ & $-0.268^{* * *}$ \\
\hline & & $(0.004)$ & $(0.004)$ & $(0.002)$ & $(0.003)$ & $(0.005)$ \\
\hline & \multirow[t]{2}{*}{ Top 5\% } & $0.188^{* * *}$ & $0.327^{* * *}$ & $0.056^{* * *}$ & $0.134^{* * *}$ & $-0.169 * * *$ \\
\hline & & $(0.017)$ & $(0.020)$ & $(0.015)$ & $(0.017)$ & $(0.017)$ \\
\hline \multicolumn{2}{|l|}{ Observations } & 907,843 & 907,843 & 907,843 & 907,843 & 907,843 \\
\hline \multicolumn{2}{|l|}{ Adj. R-squared } & 0.372 & 0.243 & 0.421 & 0.324 & 0.451 \\
\hline \multicolumn{2}{|l|}{ Control variables } & Yes & Yes & Yes & Yes & Yes \\
\hline \multicolumn{2}{|l|}{ Weights } & Yes & Yes & Yes & Yes & Yes \\
\hline \multicolumn{2}{|l|}{ Cluster } & Firm level & Firm level & Firm level & Firm level & Firm level \\
\hline
\end{tabular}

The coefficients in this table are estimated from the same specifications with the same restrictions as in table 9 using a weighted-OLS estimator, weighted by firm's sales. Standard errors, reported in parentheses, are clustered at firm level. ***, **, * indicate significance levels at $1 \%, 5 \%$ and $10 \%$. 
Table 11: The funding of tangible, intangible and financial investments: unweighted estimation

\begin{tabular}{|c|c|c|c|c|c|c|}
\hline & $\Delta$ Bank Credit & $\Delta$ Other Debts & $\Delta$ Equity (net of RE) & Retained Earnings & $\Delta$ Cash Holdings & $\Delta$ Residual Liab. \\
\hline$\Delta$ Tangible Fixed Assets & $\begin{array}{c}0.597^{* * *} \\
(0.002)\end{array}$ & $\begin{array}{c}0.088^{* * *} \\
(0.001)\end{array}$ & $\begin{array}{c}0.006^{* * *} \\
(0.001)\end{array}$ & $\begin{array}{c}0.107^{* * *} \\
(0.001)\end{array}$ & $\begin{array}{c}-0.094^{* * *} \\
(0.002)\end{array}$ & $\begin{array}{c}0.108^{* * *} \\
(0.001)\end{array}$ \\
\hline$\Delta$ Intangible Fixed Assets & $\begin{array}{c}0.430^{* * *} * \\
(0.006)\end{array}$ & $\begin{array}{c}0.257^{* * *} \\
(0.006)\end{array}$ & $\begin{array}{c}0.097^{* * * *} \\
(0.003)\end{array}$ & $\begin{array}{c}-0.001 \\
(0.006)\end{array}$ & $\begin{array}{c}-0.064^{* * *} \\
(0.007)\end{array}$ & $\begin{array}{c}0.154^{* * *} \\
(0.005)\end{array}$ \\
\hline$\Delta$ Financial Assets & $\begin{array}{c}0.284^{* * *} \\
(0.004)\end{array}$ & $\begin{array}{c}0.195^{* * *} \\
(0.004)\end{array}$ & $\begin{array}{c}0.029^{* * * *} \\
(0.002)\end{array}$ & $\begin{array}{c}0.143^{* * *} \\
(0.004)\end{array}$ & $\begin{array}{c}-0.240^{* * *} \\
(0.005)\end{array}$ & $\begin{array}{c}0.108^{* * *} \\
(0.003)\end{array}$ \\
\hline$\Delta$ net WCA & $\begin{array}{c}0.187^{* * * *} \\
(0.001)\end{array}$ & $\begin{array}{c}0.134^{* * * *} \\
(0.001)\end{array}$ & $\begin{array}{c}0.008^{* * *} \\
(0.000)\end{array}$ & $\begin{array}{c}0.156^{* * *} \\
(0.001)\end{array}$ & $\begin{array}{c}-0.336^{* * *} \\
(0.002)\end{array}$ & $\begin{array}{c}0.178 * * * \\
(0.001)\end{array}$ \\
\hline Observations & 907,843 & 907,843 & 907,843 & 907,843 & 907,843 & 907,843 \\
\hline Adj. R-squared & 0.460 & 0.126 & 0.589 & 0.286 & 0.503 & 0.174 \\
\hline Control variables & Yes & Yes & Yes & Yes & Yes & Yes \\
\hline Weights & No & No & No & No & No & No \\
\hline Cluster & Firm level & Firm level & Firm level & Firm level & Firm level & Firm level \\
\hline
\end{tabular}

This tables reports the contribution of several funding sources to the financing of asset components. The dependent variables are the changes in bank credit (column $(1)$ ), the changes in other debt (column (2)), the changes in equity (column (3)), the changes in retained earnings (column (4)), the changes in cash holdings (column $(5))$ and the changes in residual liabilities (column (6)). The explanatory variables are the changes in tangible fixed assets $(\Delta$ Tangible Fixed Assets), the changes in intangible fixed assets ( $\Delta$ Intangible Fixed Assets) and the changes in financial fixed assets $(\Delta$ Financial Assets), the changes in net working capital assets ( $\Delta$ net WCA) and the changes in residual assets ( $\Delta$ Residual Assets, omitted for the sake of readibility). Tangible fixed assets are composed of property, plants and equipment. By contrast, intangible fixed assets are made of goodwills, capitalized R\& D expenditures, patents, licenses and set-up costs. The same control variables are included in the regressions as in table 7. All variables are deflated using the gross fixed capital formation price index as deflator. All variables are centered at firm level. The same restrictions are imposed as in table 7 . Standard errors, reported in parentheses, are clustered at firm level. ***, **, * indicate significance levels at $1 \%, 5 \%$ and $10 \%$ 
Table 12: The funding of tangible, intangible and financial investments: weighted estimation

\begin{tabular}{|c|c|c|c|c|c|c|}
\hline & $\Delta$ Bank Credit & $\Delta$ Other Debts & $\Delta$ Equity (net of RE) & Retained Earnings & $\Delta$ Cash Holdings & $\Delta$ Residual Liab \\
\hline \multirow[t]{2}{*}{$\Delta$ Tangible Fixed Assets } & $0.436^{* * *}$ & $0.193 * * *$ & $0.070 * * *$ & $0.094^{* * *}$ & $-0.085 * * *$ & $0.122^{* * *}$ \\
\hline & $(0.015)$ & $(0.017)$ & $(0.012)$ & $(0.010)$ & $(0.017)$ & $(0.009)$ \\
\hline \multirow[t]{2}{*}{$\Delta$ Intangible Fixed Assets } & $0.230 * * *$ & $0.303^{* * *}$ & $0.169^{* *}$ & 0.007 & -0.003 & $0.287^{* * *}$ \\
\hline & $(0.026)$ & $(0.084)$ & $(0.069)$ & $(0.036)$ & $(0.024)$ & $(0.032)$ \\
\hline \multirow[t]{2}{*}{$\Delta$ Financial Assets } & $0.212^{* * *}$ & $0.288 * * *$ & $0.116^{* *}$ & $0.184^{* * *}$ & $-0.134^{* * *}$ & $0.066^{* * *}$ \\
\hline & $(0.036)$ & $(0.041)$ & $(0.045)$ & $(0.029)$ & $(0.041)$ & $(0.023)$ \\
\hline \multirow[t]{2}{*}{$\Delta$ net $\mathrm{WCA}$} & $0.190^{* * *}$ & $0.264^{* * *}$ & $0.040^{* * *}$ & $0.139 * * *$ & $-0.227^{* * *}$ & $0.139 * * *$ \\
\hline & $(0.010)$ & $(0.011)$ & $(0.010)$ & $(0.011)$ & $(0.012)$ & $(0.006)$ \\
\hline Observations & 907,843 & 907,843 & 907,843 & 907,843 & 907,843 & 907,843 \\
\hline Adj. R-squared & 0.362 & 0.223 & 0.399 & 0.304 & 0.419 & 0.151 \\
\hline Control variables & Yes & Yes & Yes & Yes & Yes & Yes \\
\hline Weights & Yes & Yes & Yes & Yes & Yes & Yes \\
\hline Cluster & Firm level & Firm level & Firm level & Firm level & Firm level & Firm level \\
\hline
\end{tabular}

The coefficients in this table are estimated from the same specifications with the same restrictions as in table 11 using a weighted-OLS estimator, weighted by firm's sales. Standard errors, reported in parentheses, are clustered at firm level. ***,**,* indicate significance levels at $1 \%, 5 \%$ and $10 \%$. 
Table 13: The funding of investments by investment size (small vs large): unweighted estimation

\begin{tabular}{|c|c|c|c|c|c|c|}
\hline & $\Delta$ Bank Credit & $\Delta$ Other Debts & $\Delta$ Equity (net of RE) & Retained Earnings & $\Delta$ Cash Holdings & $\Delta$ Residual Liab. \\
\hline$\Delta$ net Fixed Assets (Small) & $\begin{array}{c}0.476^{* * *} \\
(0.006)\end{array}$ & $\begin{array}{c}0.104^{* * *} \\
(0.006)\end{array}$ & $\begin{array}{c}0.004 \\
(0.003)\end{array}$ & $\begin{array}{c}0.234^{* * *} \\
(0.006)\end{array}$ & $\begin{array}{c}-0.051^{* * *} \\
(0.008)\end{array}$ & $\begin{array}{c}0.134^{* * *} \\
(0.006)\end{array}$ \\
\hline$\Delta$ net Fixed Assets (Large) & $\begin{array}{c}0.605^{* * *} \\
(0.002)\end{array}$ & $\begin{array}{c}0.092^{* * *} \\
(0.002)\end{array}$ & $\begin{array}{c}0.010^{* * *} \\
(0.001)\end{array}$ & $\begin{array}{c}0.092^{* * *} \\
(0.002)\end{array}$ & $\begin{array}{c}-0.096^{* * *} \\
(0.002)\end{array}$ & $\begin{array}{c}0.104^{* * *} \\
(0.002)\end{array}$ \\
\hline$\Delta$ net WCA & $\begin{array}{c}0.189^{* * * *} \\
(0.001)\end{array}$ & $\begin{array}{c}0.134^{* * *} \\
(0.001)\end{array}$ & $\begin{array}{c}0.008^{* * *} \\
(0.000)\end{array}$ & $\begin{array}{c}0.156^{* * *} \\
(0.001)\end{array}$ & $\begin{array}{c}-0.335 * * * \\
(0.002)\end{array}$ & $\begin{array}{c}0.178^{* * * *} \\
(0.001)\end{array}$ \\
\hline Observations & 907,843 & 907,843 & 907,843 & 907,843 & 907,843 & 907,843 \\
\hline Adj. R-squared & 0.456 & 0.124 & 0.589 & 0.286 & 0.502 & 0.174 \\
\hline Control variables & Yes & Yes & Yes & Yes & Yes & Yes \\
\hline Weights & No & No & No & No & No & No \\
\hline Cluster & Firm level & Firm level & Firm level & Firm level & Firm level & Firm level \\
\hline
\end{tabular}

This tables reports the contribution of several funding sources to the financing of asset components. The dependent variables are the changes in bank credit (column (1)), the changes in other debt (column (2)), the changes in equity (column (3)), the changes in retained earnings (column (4)), the changes in cash holdings (column (5)) and the changes in residual liabilities (column (6)). The changes in fixed assets are now broken down into (i) small changes in fixed assets (50\% smallest changes) and (ii) large changes (50\% largest investment). The same control variables are included in the regressions as in table 7 . All variables are deflated using the gross fixed capital formation price index as deflator. All variables are centered at firm level. The same sample restrictions are imposed as in table 7. Standard errors, reported in parentheses, are clustered at firm level. ***, **, * indicate significance levels at $1 \%, 5 \%$ and $10 \%$. 
Table 14: The funding of investments by investment size (small vs large): weighted estimation

\begin{tabular}{|c|c|c|c|c|c|c|}
\hline & $\Delta$ Bank Credit & $\Delta$ Other Debts & $\Delta$ Equity (net of RE) & Retained Earnings & $\Delta$ Cash Holdings & $\Delta$ Residual Liab. \\
\hline$\Delta$ net Fixed Assets (Small) & $\begin{array}{c}0.303^{* * *} \\
(0.062)\end{array}$ & $\begin{array}{c}0.153^{* *} \\
(0.060)\end{array}$ & $\begin{array}{c}0.056 \\
(0.042)\end{array}$ & $\begin{array}{c}0.281^{* * *} \\
(0.059)\end{array}$ & $\begin{array}{c}-0.104^{*} \\
(0.062)\end{array}$ & $\begin{array}{c}0.102^{* * *} \\
(0.035)\end{array}$ \\
\hline$\Delta$ net Fixed Assets (Large) & $\begin{array}{c}0.464^{* * *} \\
(0.020)\end{array}$ & $\begin{array}{c}0.223 * * * \\
(0.032)\end{array}$ & $\begin{array}{c}0.090^{* * *} * \\
(0.019)\end{array}$ & $\begin{array}{c}0.064^{* * *} \\
(0.018)\end{array}$ & $\begin{array}{l}-0.034 \\
(0.045)\end{array}$ & $\begin{array}{c}0.123^{* * *} * \\
(0.016)\end{array}$ \\
\hline$\Delta$ net WCA & $\begin{array}{c}0.191^{* * *} \\
(0.010)\end{array}$ & $\begin{array}{c}0.264^{* * *} \\
(0.012)\end{array}$ & $\begin{array}{c}0.040^{* * *} \\
(0.010)\end{array}$ & $\begin{array}{c}0.138^{* * *} \\
(0.010)\end{array}$ & $\begin{array}{c}-0.226 * * * \\
(0.012)\end{array}$ & $\begin{array}{c}0.140 * * * \\
(0.006)\end{array}$ \\
\hline Observations & 907,843 & 907,843 & 907,843 & 907,843 & 907,843 & 907,843 \\
\hline Adj. R-squared & 0.358 & 0.222 & 0.398 & 0.304 & 0.419 & 0.148 \\
\hline Control variables & Yes & Yes & Yes & Yes & Yes & Yes \\
\hline Weights & Yes & Yes & Yes & Yes & Yes & Yes \\
\hline Cluster & Firm level & Firm level & Firm level & Firm level & Firm level & Firm level \\
\hline
\end{tabular}

The coefficients in this table are estimated from the same specifications and the same restrictions as in table 13 using a weighted-OLS estimator, weighted by firm's sales. Standard errors, reported in parentheses, are clustered at firm level. ***, **, * indicate significance levels at $1 \%, 5 \%$ and $10 \%$. 
Table 15: The funding of investments by investment size (small, medium, large): unweighted estimation

\begin{tabular}{|c|c|c|c|c|c|c|}
\hline & $\Delta$ Bank Credit & $\Delta$ Other Debts & $\Delta$ Equity (net of RE) & Retained Earnings & $\Delta$ Cash Holdings & $\Delta$ Residual Liab \\
\hline$\Delta$ Fixed Assets (Small) & $\begin{array}{c}0.302^{* * *} \\
(0.062)\end{array}$ & $\begin{array}{c}0.153^{* *} \\
(0.060)\end{array}$ & $\begin{array}{c}0.056 \\
(0.042)\end{array}$ & $\begin{array}{c}0.282^{* * *} \\
(0.059)\end{array}$ & $\begin{array}{c}-0.104^{*} \\
(0.062)\end{array}$ & $\begin{array}{c}0.102^{* * *} \\
(0.035)\end{array}$ \\
\hline$\Delta$ Fixed Assets (Medium) & $\begin{array}{c}0.331^{* * *} \\
(0.045)\end{array}$ & $\begin{array}{c}0.302^{* * *} \\
(0.080)\end{array}$ & $\begin{array}{c}0.141^{* * *} \\
(0.045)\end{array}$ & $\begin{array}{c}0.189^{* * *} \\
(0.051)\end{array}$ & $\begin{array}{c}0.060 \\
(0.104)\end{array}$ & $\begin{array}{c}0.097^{* * *} * \\
(0.038)\end{array}$ \\
\hline$\Delta$ Fixed Assets (Large) & $\begin{array}{c}0.626^{* * *} \\
(0.036)\end{array}$ & $\begin{array}{c}0.202^{* * *} \\
(0.061)\end{array}$ & $\begin{array}{l}-0.051 \\
(0.047)\end{array}$ & $\begin{array}{c}0.077 \\
(0.054)\end{array}$ & $\begin{array}{l}-0.022 \\
(0.055)\end{array}$ & $\begin{array}{c}0.125^{* * *} \\
(0.036)\end{array}$ \\
\hline$\Delta$ net WCA & $\begin{array}{c}0.192^{* * *} \\
(0.010)\end{array}$ & $\begin{array}{c}0.264^{* * * *} \\
(0.011)\end{array}$ & $\begin{array}{c}0.040^{* * * *} \\
(0.010)\end{array}$ & $\begin{array}{c}0.138^{* * * *} \\
(0.011)\end{array}$ & $\begin{array}{c}-0.226^{* * *} \\
(0.012)\end{array}$ & $\begin{array}{c}0.140^{* * * *} \\
(0.006)\end{array}$ \\
\hline Observations & 907,843 & 907,843 & 907,843 & 907,843 & 907,843 & 907,843 \\
\hline Adj. R-squared & 0.360 & 0.223 & 0.400 & 0.305 & 0.419 & 0.149 \\
\hline Control variables & Yes & Yes & Yes & Yes & Yes & Yes \\
\hline Weights & No & No & No & No & No & No \\
\hline Cluster & Firm level & Firm level & Firm level & Firm level & Firm level & Firm level \\
\hline
\end{tabular}

This table is similar to table 13 but now we now break down investment into three size classes: small, medium, large. Small changes are changes below the median investment, medium changes are changes between the median and the $90^{\text {th }}$ percentile of investment and large changes are changes above the $90^{t h}$ percentile of investment. All variables are deflated using the gross fixed capital formation price index as deflator. All variables are centered at firm level. Standard errors, reported in parentheses, are clustered at firm level. $* * *, * *, *$ indicate significance levels at $1 \%, 5 \%$ and $10 \%$. 
Table 16: The funding of investments by investment size (small, medium, large): weighted estimation

\begin{tabular}{|c|c|c|c|c|c|c|}
\hline & $\Delta$ Bank Credit & $\Delta$ Other Debts & $\Delta$ Equity (net of RE) & Retained Earnings & $\Delta$ Cash Holdings & $\Delta$ Residual Liab. \\
\hline \multirow[t]{2}{*}{$\Delta$ Fixed Assets (Small) } & $0.475^{* * *}$ & $0.104^{* * *}$ & 0.004 & $0.234^{* * *}$ & $-0.051^{* * *}$ & $0.134^{* * *}$ \\
\hline & $(0.006)$ & $(0.006)$ & $(0.003)$ & $(0.006)$ & $(0.008)$ & $(0.006)$ \\
\hline \multirow[t]{2}{*}{$\Delta$ Fixed Assets (Medium) } & $0.504^{* * *}$ & $0.095^{* * *}$ & $0.007 * * *$ & $0.175^{* * *}$ & $-0.104^{* * *}$ & $0.114^{* * *}$ \\
\hline & $(0.004)$ & $(0.004)$ & $(0.002)$ & $(0.004)$ & $(0.005)$ & $(0.004)$ \\
\hline \multirow[t]{2}{*}{$\Delta$ Fixed Assets (Large) } & $0.645^{* * *}$ & $0.085^{* * *}$ & 0.001 & $0.082^{* * *}$ & $-0.092^{* * *}$ & $0.095 * * *$ \\
\hline & $(0.005)$ & $(0.004)$ & $(0.002)$ & $(0.004)$ & $(0.005)$ & $(0.004)$ \\
\hline \multirow[t]{2}{*}{$\Delta$ net $\mathrm{WCA}$} & $0.189^{* * *}$ & $0.134^{* * *}$ & $0.008 * * *$ & $0.156^{* * *}$ & $-0.335 * * *$ & $0.178^{* * *}$ \\
\hline & $(0.001)$ & $(0.001)$ & $(0.000)$ & $(0.001)$ & $(0.002)$ & $(0.001)$ \\
\hline Observations & 907,843 & 907,843 & 907,843 & 907,843 & 907,843 & 907,843 \\
\hline Adj. R-squared & 0.456 & 0.124 & 0.589 & 0.286 & 0.502 & 0.174 \\
\hline Control variables & Yes & Yes & Yes & Yes & Yes & Yes \\
\hline Weights & Yes & Yes & Yes & Yes & Yes & Yes \\
\hline Cluster & Firm level & Firm level & Firm level & Firm level & Firm level & Firm level \\
\hline
\end{tabular}

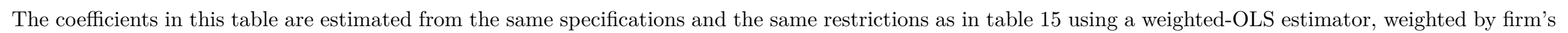
sales. Standard errors, reported in parentheses, are clustered at firm level. ***,**,* indicate significance levels at $1 \%, 5 \%$ and $10 \%$. 


\section{Appendix}

\subsection{Definition of the main variables}

This section will be completed latter as we lack of accurate translation for several accounting terms.

In this short appendix, we present the main variables used in the paper. All the variables are constructed based on the "Liasse fiscale" available online here (in French only): https://www . impots.gouv.fr/portail/files/formulaires/2050-liasse/2018/2050-liasse_2221.pdf. All the variables we use are expressed in net term, i.e. they account for depreciations and provisions of asset components, especially fixed asset.

On the asset side, we use four main variables:

- Fixed assets $\left(F A_{t}\right)$ : the sum of net tangible fixed assets, net intangible fixed assets and net financial assets

- Working capital assets $\left(W C_{t}\right)$ : the sum of inventories, trade receivables and advance on orders to suppliers

- Cash holdings $\left(\right.$ Cash $\left._{t}\right)$ : the sum of cash and marketable securities

- Residual assets $\left(R A_{t}\right)$ : the difference between the net total assets $\left(T A_{t}\right)$ and the sum of fixed assets investment, working capital investment and cash reserves.

On the liability side, we use four main variables:

- Equity (own funds), net of retained earnings $\left(E_{t}\right)$ : equity, excluding "provisions for risks and charges" and the current income net of dividend paid out

- Bank credit $\left(B C_{t}\right)$ : the sum of long-term and short-term bank credit. This component does not include leasing, factoring and other off-balance sheet items akin to bank credit.

- Trade payables $\left(T P_{t}\right)$ : the sum of "advances and down payments received" and "trade accounts payable"

- Other financial debts $\left(O D_{t}\right)$ : bonds and similar debts

- Retained earnings $\left(C F_{t}\right)$ : the current income as reported in the balance sheet (usually considered as part of the own funds) less the dividend paid out.

- Residual liabilities $\left(R L_{t}\right)$ : the difference between the net total assets and the sum of bank credit, equity, trade payables, other debts and retained earnings. 


\subsection{Additional Tables}

Table 17: The funding of investments by investment size (small vs large) and investment type (tangible vs intangible): unweighted estimation

\begin{tabular}{|c|c|c|c|c|c|c|}
\hline & $\Delta$ Bank Credit & $\Delta$ Other Debts & $\Delta$ Equity (net of RE) & Retained Earnings & $\Delta$ Cash Holdings & $\Delta$ Residual Liab. \\
\hline$\Delta$ Tangible FA (Small) & $\begin{array}{c}0.500^{* * *} \\
(0.014)\end{array}$ & $\begin{array}{c}0.089^{* * *} \\
(0.014)\end{array}$ & $\begin{array}{c}0.001 \\
(0.007)\end{array}$ & $\begin{array}{c}0.270 * * * \\
(0.014)\end{array}$ & $\begin{array}{l}-0.011 \\
(0.020)\end{array}$ & $\begin{array}{c}0.145^{* * *} \\
(0.014)\end{array}$ \\
\hline$\Delta$ Tangible FA (Large) & $\begin{array}{c}0.599 * * * \\
(0.004)\end{array}$ & $\begin{array}{c}0.098^{* * *} \\
(0.004)\end{array}$ & $\begin{array}{c}0.020^{* * *} \\
(0.002)\end{array}$ & $\begin{array}{c}0.083^{* * *} \\
(0.003)\end{array}$ & $\begin{array}{c}-0.090^{* * *} \\
(0.004)\end{array}$ & $\begin{array}{c}0.111^{* * *} \\
(0.003)\end{array}$ \\
\hline$\Delta$ Intangible FA (Small) & $\begin{array}{c}0.256^{* * *} \\
(0.064)\end{array}$ & $\begin{array}{c}0.138 * * \\
(0.066)\end{array}$ & $\begin{array}{c}0.007 \\
(0.031)\end{array}$ & $\begin{array}{c}0.276^{* * *} \\
(0.065)\end{array}$ & $\begin{array}{l}-0.038 \\
(0.083)\end{array}$ & $\begin{array}{c}0.238^{* * *} \\
(0.059)\end{array}$ \\
\hline$\Delta$ Intangible FA (Large) & $\begin{array}{c}0.414^{* * *} \\
(0.010)\end{array}$ & $\begin{array}{c}0.272^{* * *} \\
(0.010)\end{array}$ & $\begin{array}{c}0.063^{* * *} \\
(0.005)\end{array}$ & $\begin{array}{c}0.047^{* * *} \\
(0.009)\end{array}$ & $\begin{array}{c}-0.058^{* * *} \\
(0.012)\end{array}$ & $\begin{array}{c}0.138^{* * *} \\
(0.008)\end{array}$ \\
\hline$\Delta$ net $\mathrm{WCA}$ & $\begin{array}{c}0.190 * * * \\
(0.002)\end{array}$ & $\begin{array}{c}0.145^{* * * *} \\
(0.002)\end{array}$ & $\begin{array}{c}0.012^{* * *} \\
(0.001)\end{array}$ & $\begin{array}{c}0.156^{* * *} \\
(0.001)\end{array}$ & $\begin{array}{c}-0.311^{* * *} \\
(0.002)\end{array}$ & $\begin{array}{c}0.183^{* * *} \\
(0.001)\end{array}$ \\
\hline Observations & 215,674 & 215,674 & 215,674 & 215,674 & 215,674 & 215,674 \\
\hline Adj. R-squared & 0.468 & 0.141 & 0.569 & 0.286 & 0.495 & 0.183 \\
\hline Control variables & Yes & Yes & Yes & Yes & Yes & Yes \\
\hline Weights & No & No & No & No & No & No \\
\hline Cluster & Firm level & Firm level & Firm level & Firm level & Firm level & Firm level \\
\hline
\end{tabular}

This tables reports the contribution of several funding sources to the financing of tangible, intangible and net working capital assets. The dependent variables respectively are the change in bank credit (column (1)), other debt (column (2)), equity (column (3)), retained earnings (column (4)), cash holding (column (5)), residual liabilities (column (6)). Just like in table 13. small and large investment in tangible and intangible assets are defined based on the median investment.

The same control variables are set as in table 7. All variables are deflated using the gross fixed capital formation price index as deflator. All variables are centered at firm level. The same sample restrictions are applied as in table 7. Standard errors, reported in parentheses, are clustered at firm level. ***, **, * indicate significance levels at $1 \%, 5 \%$ and $10 \%$. 
Table 18: The funding of investments by investment size (small vs large) and investment type (tangible vs intangible): weighted estimation

\begin{tabular}{|c|c|c|c|c|c|c|}
\hline & $\Delta$ Bank Credit & $\Delta$ Other Debts & $\Delta$ Equity (net of RE) & Retained Earnings & $\Delta$ Cash Holdings & $\Delta$ Residual Liab. \\
\hline \multirow[t]{2}{*}{$\Delta$ Tangible FA (Small) } & 0.164 & 0.050 & 0.032 & $0.306^{* * *}$ & -0.227 & $0.210^{* * *}$ \\
\hline & $(0.130)$ & $(0.219)$ & $(0.114)$ & $(0.072)$ & $(0.227)$ & $(0.051)$ \\
\hline \multirow[t]{2}{*}{$\Delta$ Tangible FA (Large) } & $0.452^{* * *}$ & $0.169^{* * *}$ & $0.149^{* * *}$ & -0.006 & $-0.108^{* * *}$ & $0.126^{* * *}$ \\
\hline & $(0.028)$ & $(0.062)$ & $(0.055)$ & $(0.044)$ & $(0.042)$ & $(0.027)$ \\
\hline \multirow[t]{2}{*}{$\Delta$ Intangible FA (Small) } & 0.376 & -0.336 & -0.158 & 0.403 & 0.165 & $0.618^{* *}$ \\
\hline & $(0.299)$ & $(0.739)$ & $(0.332)$ & $(0.332)$ & $(0.417)$ & $(0.288)$ \\
\hline \multirow[t]{2}{*}{$\Delta$ Intangible FA (Large) } & $0.228^{* * *}$ & $0.287^{* * *}$ & $0.126^{* * *}$ & 0.051 & 0.076 & $0.297^{* * *}$ \\
\hline & $(0.036)$ & $(0.080)$ & $(0.042)$ & $(0.039)$ & $(0.082)$ & $(0.059)$ \\
\hline \multirow[t]{2}{*}{$\Delta$ net $\mathrm{WCA}$} & $0.176^{* * *}$ & $0.314^{* * *}$ & $0.048^{* * *}$ & $0.114^{* * *}$ & $-0.213^{* * *}$ & $0.143^{* * *}$ \\
\hline & $(0.011)$ & $(0.024)$ & $(0.008)$ & $(0.009)$ & $(0.015)$ & $(0.010)$ \\
\hline Observations & 215,674 & 215,674 & 215,674 & 215,674 & 215,674 & 215,674 \\
\hline Adj. R-squared & 0.365 & 0.254 & 0.395 & 0.302 & 0.430 & 0.193 \\
\hline Control variables & Yes & Yes & Yes & Yes & Yes & Yes \\
\hline Weights & Yes & Yes & Yes & Yes & Yes & Yes \\
\hline Cluster & Firm level & Firm level & Firm level & Firm level & Firm level & Firm level \\
\hline
\end{tabular}

The coefficients in this table are estimated from the same specification as in table 17 using a weighted-OLS estimator, weighted by firm's sales. Standard errors, reported in parentheses, are clustered at firm level. ${ }^{* * *},{ }^{* *}, *$ indicate significance levels at $1 \%, 5 \%$ and $10 \%$. 
Table 19: The funding of investments by investment size (small vs large) and firm size: unweighted estimation (1/2)

\begin{tabular}{|c|c|c|c|c|c|c|}
\hline & & $\Delta$ Bank Credit & $\Delta$ Other Debts & $\Delta$ Equity (net of RE) & Retained Earnings & $\Delta$ Cash Holdings \\
\hline \multirow{12}{*}{$\Delta$ Fixed Assets $($ Small $) \times$} & Bottom $25 \%$ & $0.502^{* * *}$ & $0.100^{* * *}$ & -0.001 & $0.154^{* * *}$ & $-0.179^{* * *}$ \\
\hline & & $(0.015)$ & $(0.014)$ & $(0.007)$ & $(0.015)$ & $(0.021)$ \\
\hline & ]p25-p50] & $0.503^{* * *}$ & $0.087^{* * *}$ & $-0.020^{* * *}$ & $0.216^{* * *}$ & $-0.145^{* * *}$ \\
\hline & & $(0.014)$ & $(0.012)$ & $(0.006)$ & $(0.013)$ & $(0.018)$ \\
\hline & ]p50-p75] & $0.519^{* * *}$ & $0.070^{* * *}$ & -0.005 & $0.196^{* * *}$ & $-0.138^{* * *}$ \\
\hline & & $(0.012)$ & $(0.011)$ & $(0.006)$ & $(0.011)$ & $(0.016)$ \\
\hline & ]p75-p90] & $0.489^{* * *}$ & $0.111^{* * *}$ & 0.011 & $0.210^{* * *}$ & $-0.071^{* * *}$ \\
\hline & & $(0.014)$ & $(0.014)$ & $(0.007)$ & $(0.013)$ & $(0.018)$ \\
\hline & ]p90-p95] & $0.468^{* * *}$ & $0.164^{* * *}$ & 0.007 & $0.197^{* * *}$ & $-0.049^{*}$ \\
\hline & & $(0.024)$ & $(0.023)$ & $(0.012)$ & $(0.020)$ & $(0.027)$ \\
\hline & Top 5\% & $0.359^{* * *}$ & $0.194^{* * *}$ & $0.069^{* * *}$ & $0.213^{* * *}$ & -0.020 \\
\hline & & $(0.020)$ & $(0.023)$ & $(0.012)$ & $(0.018)$ & $(0.022)$ \\
\hline \multirow{12}{*}{$\Delta$ Fixed Assets (Large) $\times$} & Bottom 25\% & $0.650^{* * *}$ & $0.078^{* * *}$ & $0.003^{*}$ & $0.088^{* * *}$ & $-0.105^{* * *}$ \\
\hline & & $(0.004)$ & $(0.003)$ & $(0.002)$ & $(0.003)$ & $(0.004)$ \\
\hline & ]p25-p50] & $0.624^{* * *}$ & $0.076^{* * *}$ & $0.006^{* * *}$ & $0.091^{* * *}$ & $-0.115^{* * *}$ \\
\hline & & $(0.004)$ & $(0.003)$ & $(0.002)$ & $(0.003)$ & $(0.004)$ \\
\hline & ]p50-p75] & $0.595^{* * *}$ & $0.096^{* * *}$ & $0.011^{* * *}$ & $0.081^{* * *}$ & $-0.120^{* * *}$ \\
\hline & & $(0.004)$ & $(0.003)$ & $(0.002)$ & $(0.003)$ & $(0.004)$ \\
\hline & ]p75-p90] & $0.567^{* * *}$ & $0.126^{* * *}$ & $0.019^{* * *}$ & $0.061^{* * *}$ & $-0.114^{* * *}$ \\
\hline & & $(0.006)$ & $(0.005)$ & $(0.003)$ & $(0.004)$ & $(0.006)$ \\
\hline & ]p90-p95] & $0.522^{* * *}$ & $0.143^{* * *}$ & $0.032^{* * *}$ & $0.065^{* * *}$ & $-0.100^{* * *}$ \\
\hline & & $(0.011)$ & $(0.009)$ & $(0.005)$ & $(0.007)$ & $(0.009)$ \\
\hline & Top 5\% & $0.409^{* * *}$ & $0.225^{* * *}$ & $0.073^{* * *}$ & $0.055^{* * *}$ & $-0.094^{* * *}$ \\
\hline & & $(0.012)$ & $(0.012)$ & $(0.006)$ & $(0.007)$ & $(0.010)$ \\
\hline
\end{tabular}


Table 19: Continued $(2 / 2)$

\begin{tabular}{lccccc} 
Observations & 907,843 & 907,843 & 907,843 & 907,843 & 0.331 \\
Adj. R-squared & 0.461 & 0.135 & 0.592 & Yes & 0.536 \\
Control variables & Yes & Yes & Yes & Yes & No \\
Weights & No & No & No & Fo & Firm level level \\
Cluster & Firm level & Firm level & Firm level & Firm \\
\hline
\end{tabular}

This tables reports the contribution of several funding sources to the financing of investment. The dependent variables respectively are the change in bank credit (column (1)), other debt (column (2)), equity (column (3)), retained earnings (column (4)), cash holding (column (5)), residual liabilities (column (6)). The change in fixed assets are broke down into small changes in fixed assets (50\% smallest changes) and large changes (50\% largest investment) and further broke down by firm size class. The firm size class are defined based on quantiles of the yearly distribution of firm sales. The same control variables are set as in table 7. All variables are deflated using the gross fixed capital formation price index as deflator. All variables are centered at firm level. The same sample restrictions are applied as in table 7. Standard errors, reported in parentheses, are clustered at firm level. ***, **, * indicate significance levels at $1 \%, 5 \%$ and $10 \%$. 
Table 20: The funding of investments by investment size (small vs large) and firm size: weighted estimation $(1 / 2)$

\begin{tabular}{|c|c|c|c|c|c|c|}
\hline & & $\Delta$ Bank Credit & $\Delta$ Other Debts & $\Delta$ Equity (net of RE) & Retained Earnings & $\Delta$ Cash Holdings \\
\hline \multirow{12}{*}{$\Delta$ Fixed Assets $($ Small $) \times$} & Bottom 25\% & $0.504^{* * *}$ & $0.105^{* * *}$ & -0.002 & $0.159^{* * *}$ & $-0.170^{* * *}$ \\
\hline & & $(0.015)$ & $(0.014)$ & $(0.007)$ & $(0.015)$ & $(0.021)$ \\
\hline & ]p25-p50] & $0.500^{* * *}$ & $0.088^{* * *}$ & $-0.021^{* * *}$ & $0.221^{* * *}$ & $-0.143^{* * *}$ \\
\hline & & $(0.014)$ & $(0.013)$ & $(0.006)$ & $(0.014)$ & $(0.018)$ \\
\hline & ]p50-p75] & $0.518^{* * *}$ & $0.066^{* * *}$ & -0.005 & $0.206^{* * *}$ & $-0.134^{* * *}$ \\
\hline & & $(0.012)$ & $(0.011)$ & $(0.006)$ & $(0.012)$ & $(0.016)$ \\
\hline & ]p75-p90] & $0.495^{* * *}$ & $0.118^{* * *}$ & 0.009 & $0.209^{* * *}$ & $-0.061^{* * *}$ \\
\hline & & $(0.015)$ & $(0.015)$ & $(0.008)$ & $(0.013)$ & $(0.019)$ \\
\hline & ]p90-p95] & $0.467^{* * *}$ & $0.169^{* * *}$ & 0.007 & $0.204^{* * *}$ & -0.037 \\
\hline & & $(0.024)$ & $(0.024)$ & $(0.012)$ & $(0.021)$ & $(0.027)$ \\
\hline & Top $5 \%$ & $0.261^{* * *}$ & $0.161^{* *}$ & 0.074 & $0.297^{* * *}$ & -0.110 \\
\hline & & $(0.079)$ & $(0.078)$ & $(0.054)$ & $(0.074)$ & $(0.074)$ \\
\hline \multirow{12}{*}{$\Delta$ Fixed Assets (Large) $\times$} & Bottom 25\% & $0.649^{* * *}$ & $0.077^{* * *}$ & $0.003^{*}$ & $0.088^{* * *}$ & $-0.106^{* * *}$ \\
\hline & & $(0.004)$ & $(0.003)$ & $(0.002)$ & $(0.003)$ & $(0.004)$ \\
\hline & ]p25-p50] & $0.621^{* * *}$ & $0.077^{* * *}$ & $0.006^{* * *}$ & $0.092^{* * *}$ & $-0.114^{* * *}$ \\
\hline & & $(0.004)$ & $(0.003)$ & $(0.002)$ & $(0.003)$ & $(0.004)$ \\
\hline & ]p50-p75] & $0.591^{* * *}$ & $0.098^{* * *}$ & $0.012^{* * *}$ & $0.081^{* * *}$ & $-0.121^{* * *}$ \\
\hline & & $(0.004)$ & $(0.004)$ & $(0.002)$ & $(0.003)$ & $(0.004)$ \\
\hline & ]p75-p90] & $0.567^{* * *}$ & $0.127^{* * *}$ & $0.020^{* * *}$ & $0.060^{* * *}$ & $-0.111^{* * *}$ \\
\hline & & $(0.006)$ & $(0.005)$ & $(0.003)$ & $(0.004)$ & $(0.006)$ \\
\hline & ]p90-p95] & $0.522^{* * *}$ & $0.145^{* * *}$ & $0.032^{* * *}$ & $0.065^{* * *}$ & $-0.098^{* * *}$ \\
\hline & & $(0.011)$ & $(0.010)$ & $(0.005)$ & $(0.007)$ & $(0.009)$ \\
\hline & Top 5\% s & $0.316^{* * *}$ & $0.332^{* * *}$ & $0.163^{* * *}$ & 0.055 & -0.002 \\
\hline & & $(0.032)$ & $(0.053)$ & $(0.035)$ & $(0.037)$ & $(0.076)$ \\
\hline
\end{tabular}


Table 20: Continued $(2 / 2)$

\begin{tabular}{lccccc} 
Observations & 907,843 & 907,843 & 907,843 & 907,843 & 0.326 \\
Adj. R-squared & 0.373 & 0.243 & 0.421 & Yes & 0.452 \\
Control variables & Yes & Yes & Yes & Yes & Yes \\
Weights & Yes & Yes & Yes & Firm level & Firm level \\
Cluster & Firm level & Firm level & Firm level & Fes \\
\hline
\end{tabular}

The coefficients in this table are estimated from the same specification as in table 19 using a weighted-OLS estimator, weighted by firm's sales. Standard errors, reported in parentheses, are clustered at firm level. ${ }^{* * *},{ }^{* *},{ }^{*}$ indicate significance levels at $1 \%, 5 \%$ and $10 \%$. 
Table 21: The funding of investments taking into account time-related dependencies: weighted estimation

$\Delta$ Bank Credit $\Delta$ Other Debts $\Delta$ Equity (net of RE) Retained Earnings $\Delta$ Cash Holdings

$\Delta$ Residual Liab.

\begin{tabular}{|c|c|c|c|c|c|c|}
\hline$\Delta$ Tangible Fixed Assets & $\begin{array}{c}0.439 * * * \\
(0.015)\end{array}$ & $\begin{array}{c}0.188^{* * *} \\
(0.018)\end{array}$ & $\begin{array}{c}0.079^{* * *} * \\
(0.011)\end{array}$ & $\begin{array}{c}0.078^{* * *} \\
(0.015)\end{array}$ & $\begin{array}{c}-0.090^{* * *} \\
(0.021)\end{array}$ & $\begin{array}{c}0.126^{* * *} \\
(0.011)\end{array}$ \\
\hline \multirow[t]{2}{*}{$\Delta$ Intangible Fixed Assets } & $0.274^{* * *}$ & $0.325^{* * *}$ & $0.126^{* *}$ & 0.025 & -0.006 & $0.243^{* * *}$ \\
\hline & $(0.026)$ & $(0.080)$ & $(0.063)$ & $(0.037)$ & $(0.032)$ & $(0.032)$ \\
\hline \multirow[t]{2}{*}{$\Delta$ Financial Assets } & $0.207^{* * *}$ & $0.268^{* * *}$ & $0.128^{* * *}$ & $0.173^{* * *}$ & $-0.131^{* * *}$ & $0.094^{* * *}$ \\
\hline & $(0.033)$ & $(0.041)$ & $(0.049)$ & $(0.024)$ & $(0.042)$ & $(0.021)$ \\
\hline \multirow[t]{2}{*}{$\Delta$ net $\mathrm{WCA}$} & $0.189 * * *$ & $0.255^{* * *}$ & $0.045^{* * *}$ & $0.150 * * *$ & $-0.215^{* * *}$ & $0.146^{* * *}$ \\
\hline & $(0.012)$ & $(0.012)$ & $(0.010)$ & $(0.016)$ & $(0.014)$ & $(0.006)$ \\
\hline \multirow[t]{2}{*}{$\Delta$ Residual Assets } & $0.186^{* * *}$ & $0.266^{* * *}$ & $0.042^{* * *}$ & $0.152^{* * *}$ & $-0.209^{* * *}$ & $0.144^{* * *}$ \\
\hline & $(0.018)$ & $(0.014)$ & $(0.009)$ & $(0.013)$ & $(0.016)$ & $(0.010)$ \\
\hline \multirow[t]{2}{*}{$\Delta$ Bank Credit (lagged) } & $-0.188^{* * *}$ & $0.071^{* * *}$ & $0.016^{* *}$ & $0.039^{* * *}$ & -0.028 & $0.035^{* * *}$ \\
\hline & $(0.013)$ & $(0.020)$ & $(0.007)$ & $(0.013)$ & $(0.022)$ & $(0.007)$ \\
\hline \multirow[t]{2}{*}{$\Delta$ Other Debts (lagged) } & $0.041^{*}$ & $-0.115^{* * *}$ & $0.037^{* * *}$ & $0.022^{* * *}$ & -0.015 & 0.001 \\
\hline & $(0.023)$ & $(0.026)$ & $(0.011)$ & $(0.007)$ & $(0.012)$ & $(0.009)$ \\
\hline \multirow[t]{2}{*}{$\Delta$ Equity (net of RE) (lagged) } & $0.062 * * *$ & 0.007 & $-0.139^{* * *}$ & $0.150 * * *$ & $0.073^{* *}$ & -0.004 \\
\hline & $(0.023)$ & $(0.036)$ & $(0.015)$ & $(0.025)$ & $(0.030)$ & $(0.012)$ \\
\hline \multirow[t]{2}{*}{ Retained Earnings (lagged) } & $-0.080^{* * *}$ & $-0.074^{* * *}$ & -0.003 & $-0.048^{* * *}$ & $-0.232^{* * *}$ & $-0.028^{* * *}$ \\
\hline & $(0.008)$ & $(0.015)$ & $(0.012)$ & $(0.009)$ & $(0.013)$ & $(0.008)$ \\
\hline \multirow[t]{2}{*}{$\Delta$ Cash Holding (lagged) } & 0.020 & 0.001 & $0.231^{* * *}$ & -0.035 & $0.237^{* * *}$ & 0.021 \\
\hline & $(0.020)$ & $(0.040)$ & $(0.014)$ & $(0.037)$ & $(0.028)$ & $(0.014)$ \\
\hline \multirow{2}{*}{$\Delta$ Residual Liab. (lagged) } & $0.049^{* * *}$ & 0.023 & $0.022^{* *}$ & $0.102^{* * *}$ & 0.012 & $-0.183^{* * *}$ \\
\hline & $(0.014)$ & $(0.022)$ & $(0.011)$ & $(0.011)$ & $(0.013)$ & $(0.013)$ \\
\hline Observations & 749,532 & 749,532 & 749,532 & 749,532 & 749,532 & 749,532 \\
\hline Adj. R-squared & 0.413 & 0.254 & 0.479 & 0.349 & 0.498 & 0.180 \\
\hline Control variables & Yes & Yes & Yes & Yes & Yes & Yes \\
\hline Weights & Yes & Yes & Yes & Yes & Yes & Yes \\
\hline Cluster & Firm level & Firm level & Firm level & Firm level & Firm level & Firm level \\
\hline
\end{tabular}

The coefficients in this table are estimated from the same specification as in table 11, but including lagged variables to take into account the intertemporal dependencies in investment and financing decisions Standard errors, reported in parentheses, are clustered at firm level. $* * *, * *, *$ indicate significance levels at $1 \%, 5 \%$ and $10 \%$. 
Table 22: The funding of investments: restricting the sample to independent firms

\begin{tabular}{|c|c|c|c|c|c|c|}
\hline & $\Delta$ Bank Credit & $\Delta$ Other Debts & $\Delta$ Equity (net of RE) & Retained Earnings & $\Delta$ Cash Holdings & $\Delta$ Residual Liab. \\
\hline$\Delta$ Tangible Fixed Assets & $\begin{array}{c}0.570^{* * *} \\
(0.013)\end{array}$ & $\begin{array}{c}0.087^{* * *} \\
(0.012)\end{array}$ & $\begin{array}{c}0.038^{* *} \\
(0.015)\end{array}$ & $\begin{array}{c}0.119^{* * *} \\
(0.010)\end{array}$ & $\begin{array}{c}-0.086^{* * *} \\
(0.010)\end{array}$ & $\begin{array}{c}0.100^{* * *} \\
(0.010)\end{array}$ \\
\hline$\Delta$ Intangible Fixed Assets & $\begin{array}{c}0.357^{* * *} \\
(0.047)\end{array}$ & $\begin{array}{c}0.259^{* * *} \\
(0.029)\end{array}$ & $\begin{array}{c}0.139^{* * *} \\
(0.016)\end{array}$ & $\begin{array}{l}0.051^{*} \\
(0.027)\end{array}$ & $\begin{array}{c}0.012 \\
(0.036)\end{array}$ & $\begin{array}{c}0.206^{* * *} \\
(0.061)\end{array}$ \\
\hline$\Delta$ Financial Assets & $\begin{array}{c}0.287^{* * *} \\
(0.033)\end{array}$ & $\begin{array}{c}0.227^{* * *} \\
(0.055)\end{array}$ & $\begin{array}{l}-0.021 \\
(0.058)\end{array}$ & $\begin{array}{c}0.161^{* * *} \\
(0.022)\end{array}$ & $\begin{array}{c}-0.264^{* * *} \\
(0.034)\end{array}$ & $\begin{array}{c}0.085^{* *} \\
(0.038)\end{array}$ \\
\hline$\Delta$ net WCA & $\begin{array}{c}0.218^{* * *} \\
(0.011)\end{array}$ & $\begin{array}{c}0.116^{* * *} \\
(0.019)\end{array}$ & $\begin{array}{c}0.011^{* * * *} \\
(0.002)\end{array}$ & $\begin{array}{c}0.129^{* * *} \\
(0.005)\end{array}$ & $\begin{array}{c}-0.374^{* * *} \\
(0.012)\end{array}$ & $\begin{array}{c}0.152^{* * *} \\
(0.006)\end{array}$ \\
\hline$\Delta$ residual Assets & $\begin{array}{c}0.246^{* * *} \\
(0.015)\end{array}$ & $\begin{array}{c}0.181^{* * * *} \\
(0.028)\end{array}$ & $\begin{array}{l}-0.012 \\
(0.009)\end{array}$ & $\begin{array}{c}0.099 * * * \\
(0.008)\end{array}$ & $\begin{array}{c}-0.356^{* * *} \\
(0.013)\end{array}$ & $\begin{array}{c}0.129 * * * \\
(0.017)\end{array}$ \\
\hline Observations & 466,153 & 466,153 & 466,153 & 466,153 & 466,153 & 466,153 \\
\hline Adj. R-squared & 0.450 & 0.123 & 0.440 & 0.277 & 0.494 & 0.178 \\
\hline Control variables & Yes & Yes & Yes & Yes & Yes & Yes \\
\hline Weights & Yes & Yes & Yes & Yes & Yes & Yes \\
\hline Cluster & Firm level & Firm level & Firm level & Firm level & Firm level & Firm level \\
\hline
\end{tabular}

The coefficients in this table are estimated from the same specification as in table 11, but the estimation is here restricted to independent firms. Standard errors, reported in parentheses, are clustered at firm level. ${ }^{* * *},{ }^{* *}, *$ indicate significance levels at $1 \%, 5 \%$ and $10 \%$. 
Table 23: The funding of investments: restricting the estimation to firms borrowing bank credit

\begin{tabular}{|c|c|c|c|c|c|c|}
\hline & $\Delta$ Bank Credit & $\Delta$ Other Debts & $\Delta$ Equity (net of RE) & Retained Earnings & $\Delta$ Cash Holdings & $\Delta$ Residual Liab. \\
\hline \multirow[t]{2}{*}{$\Delta$ Tangible Fixed Assets } & $0.456^{* * *}$ & $0.176^{* * *}$ & $0.046^{* * *}$ & $0.087^{* * *}$ & $-0.111^{* * *}$ & $0.122^{* * *}$ \\
\hline & $(0.017)$ & $(0.025)$ & $(0.013)$ & $(0.018)$ & $(0.023)$ & $(0.013)$ \\
\hline \multirow[t]{2}{*}{$\Delta$ Intangible Fixed Assets } & $0.185^{* * *}$ & $0.231^{* * *}$ & $0.312^{* * *}$ & -0.038 & -0.010 & $0.302^{* * *}$ \\
\hline & $(0.047)$ & $(0.072)$ & $(0.089)$ & $(0.045)$ & $(0.032)$ & $(0.042)$ \\
\hline \multirow{2}{*}{$\Delta$ Financial Assets } & $0.192^{* * *}$ & $0.354^{* * *}$ & 0.075 & $0.190 * * *$ & $-0.108 * * *$ & $0.082^{* *}$ \\
\hline & $(0.033)$ & $(0.067)$ & $(0.053)$ & $(0.052)$ & $(0.032)$ & $(0.037)$ \\
\hline \multirow[t]{2}{*}{$\Delta$ net WCA } & $0.172^{* * *}$ & $0.266^{* * *}$ & $0.040 * * *$ & $0.135^{* * *}$ & $-0.233^{* * *}$ & $0.154^{* * *}$ \\
\hline & $(0.008)$ & $(0.016)$ & $(0.010)$ & $(0.006)$ & $(0.011)$ & $(0.010)$ \\
\hline \multirow[t]{2}{*}{$\Delta$ Residual Assets } & $0.172^{* * *}$ & $0.275^{* * *}$ & $0.041^{* * *}$ & $0.132^{* * *}$ & $-0.231^{* * *}$ & $0.148^{* * *}$ \\
\hline & $(0.010)$ & $(0.016)$ & $(0.008)$ & $(0.009)$ & $(0.020)$ & $(0.010)$ \\
\hline Observations & 472,267 & 472,267 & 472,267 & 472,267 & 472,267 & 472,267 \\
\hline Adj. R-squared & 0.458 & 0.239 & 0.402 & 0.307 & 0.469 & 0.176 \\
\hline Control variables & Yes & Yes & Yes & Yes & Yes & Yes \\
\hline Weights & Yes & Yes & Yes & Yes & Yes & Yes \\
\hline Cluster & Firm level & Firm level & Firm level & Firm level & Firm level & Firm level \\
\hline
\end{tabular}

The coefficients in this table are estimated from the same specification as in table 11, but the estimation is here restricted to firms borrowing bank credit (i.e. a strictly positive change in bank credit). Standard errors, reported in parentheses, are clustered at firm level. ${ }^{* *},{ }^{* *}, *$ indicate significance levels at $1 \%, 5 \%$ and $10 \%$. 
Table 24: The funding of investments: taking into account disinvestment

\begin{tabular}{|c|c|c|c|c|c|c|}
\hline & $\Delta$ Bank Credit & $\Delta$ Other Debts & $\Delta$ Equity (net of RE) & Retained Earnings & $\Delta$ Cash Holdings & $\Delta$ Residual Liab. \\
\hline$\Delta$ Tangible Fixed Assets & $\begin{array}{c}0.438^{* * *} * \\
(0.010)\end{array}$ & $\begin{array}{c}0.170^{* * *} \\
(0.014)\end{array}$ & $\begin{array}{c}0.044^{* * * *} \\
(0.010)\end{array}$ & $\begin{array}{c}0.127^{* * * *} \\
(0.010)\end{array}$ & $\begin{array}{c}-0.110^{* * *} \\
(0.013)\end{array}$ & $\begin{array}{c}0.112^{* * *} \\
(0.006)\end{array}$ \\
\hline$\Delta$ Intangible Fixed Assets & $\begin{array}{c}0.178^{* * *} \\
(0.024)\end{array}$ & $\begin{array}{c}0.278^{* * *} \\
(0.076)\end{array}$ & $\begin{array}{c}0.186^{* * *} \\
(0.047)\end{array}$ & $\begin{array}{c}0.053 \\
(0.045)\end{array}$ & $\begin{array}{c}-0.050^{*} \\
(0.026)\end{array}$ & $\begin{array}{c}0.254^{* * *} \\
(0.027)\end{array}$ \\
\hline$\Delta$ Financial Assets & $\begin{array}{c}0.221^{* * *} \\
(0.020)\end{array}$ & $\begin{array}{c}0.275^{* * *} \\
(0.053)\end{array}$ & $\begin{array}{c}0.082^{* * * *} \\
(0.030)\end{array}$ & $\begin{array}{c}0.196^{* * * *} \\
(0.025)\end{array}$ & $\begin{array}{c}-0.177^{* * *} \\
(0.039)\end{array}$ & $\begin{array}{c}0.048^{* *} \\
(0.019)\end{array}$ \\
\hline$\Delta$ net WCA & $\begin{array}{c}0.188^{* * *} \\
(0.007)\end{array}$ & $\begin{array}{c}0.267^{* * *} \\
(0.009)\end{array}$ & $\begin{array}{c}0.030^{* * * *} \\
(0.006)\end{array}$ & $\begin{array}{c}0.144^{* * *} \\
(0.008)\end{array}$ & $\begin{array}{c}-0.236^{* * *} \\
(0.008)\end{array}$ & $\begin{array}{c}0.134^{* * *} \\
(0.004)\end{array}$ \\
\hline$\Delta$ residual Assets & $\begin{array}{c}0.175^{* * * *} \\
(0.007)\end{array}$ & $\begin{array}{c}0.272^{* * * *} \\
(0.009)\end{array}$ & $\begin{array}{c}0.028^{* * * *} \\
(0.006)\end{array}$ & $\begin{array}{c}0.168^{* * * *} \\
(0.007)\end{array}$ & $\begin{array}{c}-0.221^{* * *} \\
(0.012)\end{array}$ & $\begin{array}{c}0.137^{* * *} \\
(0.007)\end{array}$ \\
\hline Observations & $2,358,772$ & $2,358,772$ & $2,358,772$ & $2,358,772$ & $2,358,772$ & $2,358,772$ \\
\hline Adj. R-squared & 0.296 & 0.206 & 0.441 & 0.311 & 0.442 & 0.134 \\
\hline Control variables & Yes & Yes & Yes & Yes & Yes & Yes \\
\hline Weights & Yes & Yes & Yes & Yes & Yes & Yes \\
\hline Cluster & Firm level & Firm level & Firm level & Firm level & Firm level & Firm level \\
\hline
\end{tabular}

The coefficients in this table are estimated from the same specification as in table 11, but the restriction on strictly positive change in fixed assets (i.e. investment) is removed. As a consequence, the number of observations increases from 907,843 to 2,358,772. Standard errors, reported in parentheses, are clustered at firm level. $* * *, * *, *$ indicate significance levels at $1 \%, 5 \%$ and $10 \%$. 
Table 25: The funding of investments: relying on a definition of investment based on the acquisition of fixed assets

\begin{tabular}{|c|c|c|c|c|c|c|}
\hline & $\Delta$ Bank Credit & $\Delta$ Other Debts & $\Delta$ Equity (net of RE) & Retained Earnings & $\Delta$ Cash Holdings & $\Delta$ Residual Liab. \\
\hline Acqu. of Fixed Assets (Small) & $\begin{array}{c}0.164^{* * *} \\
(0.024)\end{array}$ & $\begin{array}{c}0.178^{* * *} \\
(0.042)\end{array}$ & $\begin{array}{l}-0.017 \\
(0.055)\end{array}$ & $\begin{array}{c}0.084^{* * *} \\
(0.020)\end{array}$ & $\begin{array}{c}-0.159^{* *} \\
(0.064)\end{array}$ & $\begin{array}{c}0.039 * * \\
(0.016)\end{array}$ \\
\hline Acqu. of Fixed Assets (Large) & $\begin{array}{c}0.212^{* * *} \\
(0.022)\end{array}$ & $\begin{array}{c}0.125^{* * *} \\
(0.026)\end{array}$ & $\begin{array}{c}0.068^{* *} \\
(0.029)\end{array}$ & $\begin{array}{c}0.015 \\
(0.028)\end{array}$ & $\begin{array}{c}-0.085 * * * \\
(0.023)\end{array}$ & $\begin{array}{c}0.051^{* * *} \\
(0.018)\end{array}$ \\
\hline$\Delta$ net WCA & $\begin{array}{c}0.190^{* * *} \\
(0.007)\end{array}$ & $\begin{array}{c}0.275^{* * *} \\
(0.010)\end{array}$ & $\begin{array}{c}0.030 * * * \\
(0.006)\end{array}$ & $\begin{array}{c}0.140^{* * *} \\
(0.008)\end{array}$ & $\begin{array}{c}-0.237^{* * *} \\
(0.009)\end{array}$ & $\begin{array}{c}0.135^{* * *} \\
(0.005)\end{array}$ \\
\hline Observations & $1,654,462$ & $1,654,462$ & $1,654,462$ & $1,654,462$ & $1,654,462$ & $1,654,462$ \\
\hline Adj. R-squared & 0.249 & 0.208 & 0.445 & 0.301 & 0.445 & 0.127 \\
\hline Control variables & Yes & Yes & Yes & Yes & Yes & Yes \\
\hline Weights & Yes & Yes & Yes & Yes & Yes & Yes \\
\hline Cluster & Firm level & Firm level & Firm level & Firm level & Firm level & Firm level \\
\hline
\end{tabular}

The coefficients in this table are estimated from the same specification as in table 14, the only difference relies on the measure of investment: the present specification relies on the acquisition of fixed assets as measure of investment. Standard errors, reported in parentheses, are clustered at firm level. $* * *, * *, *$ indicate significance levels at $1 \%, 5 \%$ and $10 \%$ 